\title{
Management Of The Piankatank River, Virginia, In Support Of Oyster (Crassostrea Virginica, Gmelin 1791) Fishery Repletion
}

\author{
Juliana M. Harding \\ Virginia Institute of Marine Science \\ Roger L. Mann \\ Virginia Institute of Marine Science \\ Melissa Southworth \\ Virginia Institute of Marine Science \\ James A. Wesson \\ Virginia Institute of Marine Science
}

Follow this and additional works at: https://scholarworks.wm.edu/vimsarticles

Part of the Marine Biology Commons

\section{Recommended Citation}

Harding, Juliana M.; Mann, Roger L.; Southworth, Melissa; and Wesson, James A., Management Of The Piankatank River, Virginia, In Support Of Oyster (Crassostrea Virginica, Gmelin 1791) Fishery Repletion (2010). Journal Of Shellfish Research, 29(4), 867-888.

$10.2983 / 035.029 .0421$

This Article is brought to you for free and open access by the Virginia Institute of Marine Science at W\&M ScholarWorks. It has been accepted for inclusion in VIMS Articles by an authorized administrator of W\&M ScholarWorks. For more information, please contact scholarworks@wm.edu. 


\title{
MANAGEMENT OF THE PIANKATANK RIVER, VIRGINIA, IN SUPPORT OF OYSTER (CRASSOSTREA VIRGINICA, GMELIN 1791) FISHERY REPLETION
}

\author{
JULIANA M. HARDING, ${ }^{1, *}$ ROGER MANN, ${ }^{1}$ MELISSA J. SOUTHWORTH ${ }^{1}$ \\ AND JAMES A. WESSON ${ }^{2}$ \\ ${ }^{1}$ Department of Fisheries Science, Virginia Institute of Marine Science, College of William and Mary, \\ Gloucester Point, VA 23062; ${ }^{2}$ Virginia Marine Resources Commission, 2600 Washington Avenue, \\ Newport News, VA 23607-0756
}

\begin{abstract}
The Piankatank River is a trap-type estuary on the western shore of Chesapeake Bay that has been managed for seed oyster production since 1963. Market oyster production in the river is minimal. Repletion efforts include shell planting and seed removal. We describe sequential changes in population demographics and habitat in relation to repletion activities on eight Piankatank River public oyster reefs from 1998 through 2009. Two reef groups (northern and southern) may be distinguished by density (oysters $/ \mathrm{m}^{2}$ ), biomass ( $\mathrm{g}$ dry tissue weight), and shell volume $\left(\mathrm{L} / \mathrm{m}^{2}\right)$ data. Age-at-length relationships were estimated from demographic data using a quadratic model. Observed mortality rates were high, and age $3+$ oysters were essentially absent. A strong recruitment signal was observed in 1999 and 2002. Between 1998 and 2009, about 30\% of the live oysters in the river were harvested as seed, corresponding to $\sim 7.5 \%$ of the total shell base in an average year. Typically, for every 5 bushels of shell planted, 1 bushel of seed was harvested $\left(20 \%\right.$ return). Even with shell planting $\left(\sim 10 \mathrm{~L} / \mathrm{m}^{2} / \mathrm{y}\right)$, the river shell budget showed a deficit with respect to the accretion rate required to balance sea level rise and natural degradation processes. During the study period, the mean river recruit-to-stock ratio was $\sim 4$. The unusual and consistently high recruit-to-stock ratios suggest that management for modest continuous seed removal may be accomplished without shell planting. Annual stock assessment to identify low recruitment years is recommended as a method to adjust annual seed harvest quotas.
\end{abstract}

KEY WORDS: Eastern oyster, Crassostrea virginica, population demographics, mortality, recruitment, repletion, shell budgets, Piankatank River, Virginia, fishery management

\section{INTRODUCTION}

The eastern oyster (Crassostrea virginica, Gmelin 1791) has been the target of commercial fisheries from Maine to Texas since the 17th century (Brooks 1891, Moore 1897, Galtsoff 1964). Eastern oysters created biogenic reef habitats in estuarine and coastal ecosystems that were sustained by sequential recruitment, growth, and mortality (Galtsoff 1964, Powell et al. 2006, Mann et al. 2009b). Over geologic time, as the Chesapeake Bay was formed by rising sea level, oyster larvae migrated into the developing estuaries from coastal waters and established the founding populations for massive reef systems that developed over thousands of years (Hargis 1999). By the late 1800s, natural oyster beds previously thought to be "inexhaustible" were depleted, and a variety of strategies were used to enhance oyster abundance to meet the increasing demand (Moore 1897). Strategies to increase oyster productivity that have been used successfully in North America include planting oyster shell on soft bottom to provide substrate for recruitment alone or in combination with planting of submarket or "seed" oysters harvested from natural reefs (Moore 1897, Chew 1983, Kennedy \& Sanford 1999). Since 1896, Virginia's oyster fishery has relied on production from public oyster grounds managed by the Virginia Marine Resources Commission (VMRC) and privately leased oyster grounds managed by individuals or companies. The distinction between public and private grounds is made on the basis of the Baylor survey (1896), which identified and set aside the most productive oyster bottom for public use. The Baylor survey was commissioned in 1892 and the resulting maps by river and county became available between 1892 and 1896 . We use

*Corresponding author. E-mail: jharding@vims.edu
1896 as the citation date because the complete map set was finished in this year.

Until the late 1950s, Virginia produced the majority of oysters in the United States (Haven et al. 1978, Haven \& Whitcomb 1986, Hargis \& Haven 1988). In 1959, the disease MSX (Haplosporidium nelsoni) appeared in the lower Chesapeake Bay, Virginia (Andrews 1968), and spread rapidly through oyster habitat with salinities at or above 15 by 1960 to 1961 (Andrews \& Wood 1967). Although mortalities from MSX reduced fishery and seed production on public grounds, production from private leases declined dramatically beginning in the early 1960s, when growers stopped planting seed (Haven et al. 1978, Hargis \& Haven 1988). In response to the decimation of the traditional seed beds in the lower James River by MSX in 1960 and 1961, the VMRC began a focused repletion program combining shell planting and seed harvest in the Piankatank River during 1963 (Haven et al. 1978).

The Piankatank River is a small Virginia estuary on the western shore of the Chesapeake Bay. It is a trap-type estuary (Andrews 1979) characterized by a single, central deep channel, a sill at the entrance, and several consecutive gyre systems in the lower river reaches. It has a small watershed (approximately 466 $\mathrm{km}^{2}$ (Chen et al. 1977)), containing predominantly forested and agricultural lands. When Captain John Smith mapped the region in 1608, he described intertidal oyster reefs in the lower part of the river (Smith (1612) in Barbour 1986). More than 3 centuries of fishing pressure have drastically reduced the spatial footprint and vertical relief of oyster populations relative to what they were before European settlement (e.g., Haven et al. 1981, Haven \& Whitcomb 1986, Hargis \& Haven 1988, Hargis \& Haven 1999, Woods et al. 2005) in the Piankatank River and the Chesapeake Bay as a whole. Leased bottom in the Piankatank 
River has been used as a source of seed by private growers to supply leases in other estuaries since at least the 1930s (Haven et al. 1978). Some shell $\left(0.5 \times 10^{6}\right.$ bu (Haven et al. 1978)) was planted in the Piankatank River as part of public repletion efforts between 1930 and 1961, given the river's reputation as a river with little available natural shell cultch (Haven et al. 1978). The bushels referred to herein are Virginia bushels (3003.9 $\mathrm{in}^{3}$ or 49.2 L).

Management of the Piankatank River public oyster as a seedproducing area from 1963 through the present has focused on the region upriver of Stove Point Neck and the sill across the mouth of the river (Fig. 1). Shells are planted in late spring or early summer to provide substrate for natural recruitment. In early spring of subsequent years, dredges are used to harvest the seed or shells with naturally recruited oysters. Seed oysters are moved out of the estuary and either applied to other public oyster areas in the state by the VMRC or sold to private lease holders for grow-out to market size and eventual harvest. Typically, 2 y are required for production of market oysters from seed, with a 1:1 ratio of return for bushels of seed planted in relation to bushels of market oysters harvested (Haven et al. 1978, Andrews 1996).

The goal of Virginia's public oyster management effort in the Piankatank River is to sustain both seed oyster productivity and the integrity of the habitat. The positive relationship between live oysters and live shell habitat is well documented (Powell et al. 2006, Powell \& Klinck 2007, Mann et al. 2009a, Mann et al. 2009b). Fishing removes both habitat and live oysters. These objectives are achieved by balancing shell planting with seed removal in the context of natural interannual variability in environmental conditions. Market oyster production within the Piankatank River is limited; only seed are harvested from the eight oyster bars examined herein. In this contribution, we examine sequential changes in oyster population demographics and habitat stability in relation to oyster repletion activities on eight Piankatank River public oyster grounds from 1998 through 2009.

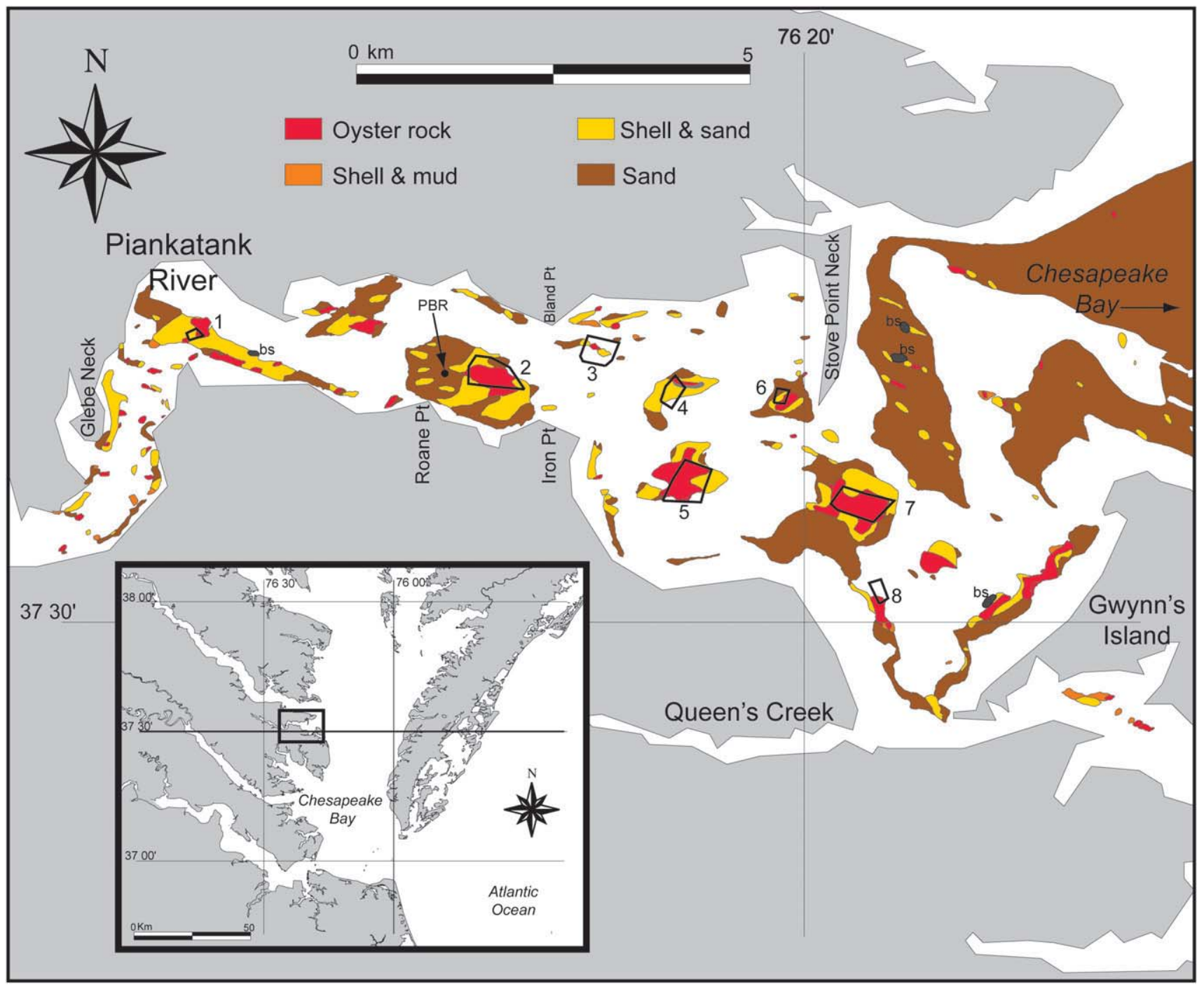

Figure 1. Map showing the locations of the eight public reefs sampled during the patent tong survey in the Piankatank River, Virginia, on an annual basis from 1998 to 2009. (1) Ginney Point, (2) Palace Bar, (3) Bland Point, (4) Heron Rock, (5) Cape Toon, (6) Stove Point (7) Burton Point, and (8) Burton Point 2. The underlying habitat types are from Haven et al. (1981). A continuous hydrographic monitoring station was established at Palace Bar Reef (PBR) in 2005. bs = locations of buried shell described by Haven et al. (1981). 
TABLE 1.

Relationship between York (YK) and Piankatank (PR) River daily average bottom water temperature and salinity (2005 to 2009) as described by month-specific linear models $(\mathrm{PR}=\mathrm{b}+\mathbf{m} \times[\mathrm{YK}])$.

\begin{tabular}{lcrrcccc}
\hline \hline Relationship & Month & \multicolumn{1}{c}{$\boldsymbol{n}$} & \multicolumn{1}{c}{ b } & SE b & m & SE $\mathbf{m}$ & $\boldsymbol{R}^{\mathbf{2}}$ \\
\hline $\begin{array}{l}\text { Water } \\
\text { temperature }\end{array}$ & Jan & 116 & -0.8152 & 0.1110 & 1.0554 & 0.0157 & 0.98 \\
& & & & & & & \\
& Feb & 138 & -2.9435 & 0.1499 & 1.7044 & 0.0293 & 0.97 \\
& Mar & 123 & -1.3473 & 0.1526 & 1.3311 & 0.0187 & 0.98 \\
& Apr & 119 & -7.3286 & 0.3235 & 1.6794 & 0.0243 & 0.98 \\
& May & 115 & 6.7040 & 1.0800 & 0.6756 & 0.0560 & 0.56 \\
& June & 111 & 1.1263 & 0.3698 & 0.9731 & 0.0151 & 0.97 \\
& July & 97 & 4.8074 & 1.1933 & 0.8471 & 0.0446 & 0.79 \\
Salinity & Aug & 143 & 0.5257 & 0.3728 & 1.0042 & 0.0134 & 0.98 \\
& Sept & 146 & -1.3186 & 0.4580 & 1.0637 & 0.0184 & 0.96 \\
& Oct & 154 & -0.9621 & 0.1534 & 1.0331 & 0.0076 & 0.99 \\
& Nov & 119 & -0.1889 & 0.1747 & 0.9859 & 0.0129 & 0.98 \\
& Dec & 121 & -0.8583 & 0.0728 & 1.0347 & 0.0082 & 0.99 \\
& Jan & 115 & -2.1813 & 0.6538 & 0.9201 & 0.0324 & 0.88 \\
& Feb & 93 & -6.8506 & 1.0746 & 1.0993 & 0.0524 & 0.83 \\
& Mar & 123 & -2.0681 & 1.3475 & 0.8474 & 0.0700 & 0.55 \\
& Apr & 119 & 7.9222 & 1.1244 & 0.2901 & 0.0622 & 0.16 \\
& May & 113 & 3.9029 & 1.6598 & 0.4768 & 0.0949 & 0.18 \\
& June & 100 & -1.0619 & 1.1462 & 0.8083 & 0.0622 & 0.63 \\
& July & 97 & 0.9733 & 1.5621 & 0.6950 & 0.0767 & 0.46 \\
& Aug & 139 & -0.8025 & 1.4446 & 0.8076 & 0.0688 & 0.50 \\
& Sept & 146 & 6.7938 & 0.9424 & 0.4820 & 0.0450 & 0.44 \\
& Oct & 154 & 1.7328 & 0.6881 & 0.7345 & 0.0321 & 0.77 \\
& Nov & 119 & 2.7338 & 0.4472 & 0.6993 & 0.0209 & 0.91 \\
& Dec & 121 & -3.1928 & 0.5431 & 0.9774 & 0.0259 & 0.92 \\
\hline
\end{tabular}

The number of data points in each month $(n)$ is given.

\section{MATERIALS AND METHODS}

Survey methods for the current Piankatank River study follow those used in the James (Mann et al. 2009b) and Great Wicomico Rivers (Southworth et al. 2010b). Oysters were collected during the fall (November) from eight natural oyster reefs within the public grounds from 1998 through 2009, in the
Piankatank River (Fig. 1). A quantitative sampling program was used along with a stratified random grid with individual oyster reefs (bars) forming the strata (Mann et al. 2009b, Southworth et al. 2010b). Reef names and locations for the public reefs (Fig. 1) adhere to those used by Baylor (1896) and subsequently resurveyed by Haven et al. (1981).

Ginney Point and Palace Bar are north of Roane Point within a gyre whereas the other 6 reefs are between Bland Point and Stove Point within a second gyre system facilitated by the presence of both Stove Point Neck and a sill running southeast across the river between Stove Point and Gwynn's Island. The combination of Stove Point Neck and the sill restrict the entrance to the river. Andrews (1979) lists a restricted entrance and low tidal flushing rates as characteristics of a trap-type estuary. Tidal range at the study sites in the Piankatank River is approximately $0.4 \mathrm{~m}$ (Chen et al. 1977). Maximum tidal currents south of Stove Point Neck are $30 \mathrm{~cm} / \mathrm{sec}$, whereas tidal currents north of Stove Point, in the study area, are $\sim 12 \mathrm{~cm} / \mathrm{sec}$ (Chen et al. 1977), yielding relatively low tidal flushing rates between Glebe Neck and Stove Point Neck.

\section{Temperature and Salinity}

Water temperature was measured on a weekly basis from June through September at 7 sites (all reefs but Burton Point 2; Fig. 1) throughout the study period. From 1998 to 2004, water samples were collected approximately $0.5 \mathrm{~m}$ off the bottom, and temperature was measured with an alcohol thermometer within 5 min of water sample collection. Beginning in 2005, water temperature was measured with a handheld digital probe suspended $0.5 \mathrm{~m}$ from the bottom. Data collected within a single week were consistently within a $1^{\circ} \mathrm{C}$ range and were averaged across all sites.

Beginning in June 2005, temperature was also measured at 15-min intervals with a YSI (Yellow Springs Instrument Company, Yellow Springs, OH) 600 series sonde mounted 0.5 $\mathrm{m}$ above the bottom at Palace Bar Reef (PBR), a 3-dimensional constructed shell reef (Fig. 1). Monthly linear regressions (Piankatank temperature $=\mathrm{b}+\mathrm{m} \times($ York temperature $)$ between measured water temperatures at PBR and a similar sonde deployed in the York River (Gloucester Point VA,

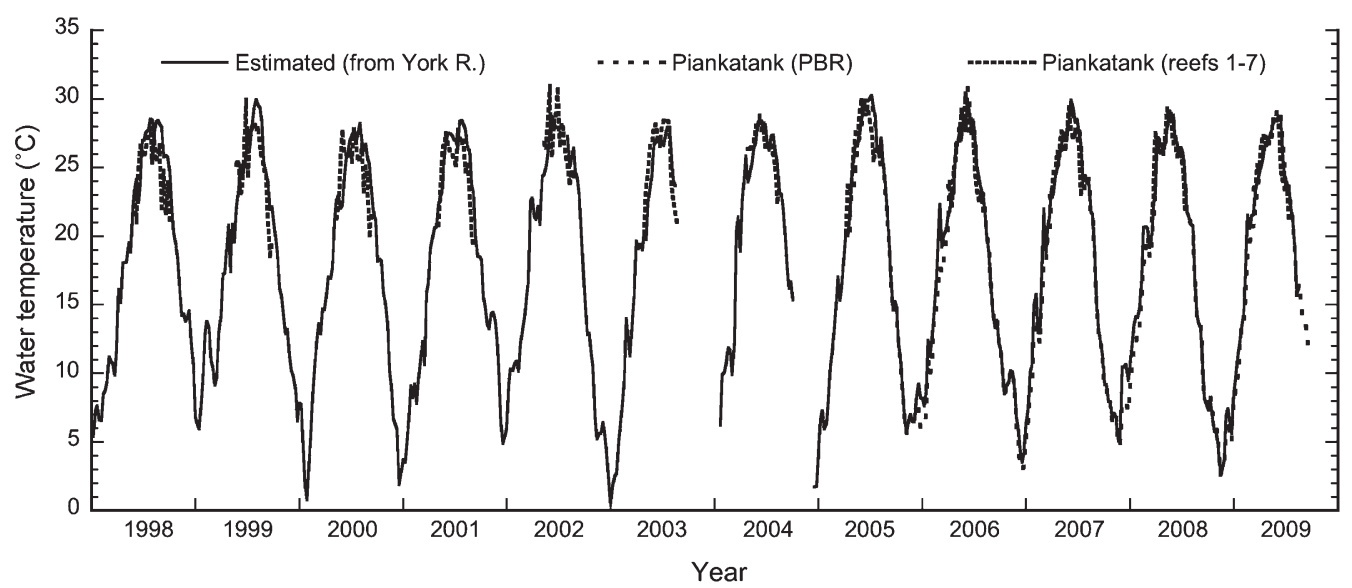

Figure 2. Average weekly bottom temperature estimated from the York River (continuous, solid line) and Piankatank River measurements at Palace Bar Reef (PBR; continuous, 2005 to 2009) and all public reefs but Burton Point 2 (weekly averages, June to September 1998 to 2009; dotted line). 


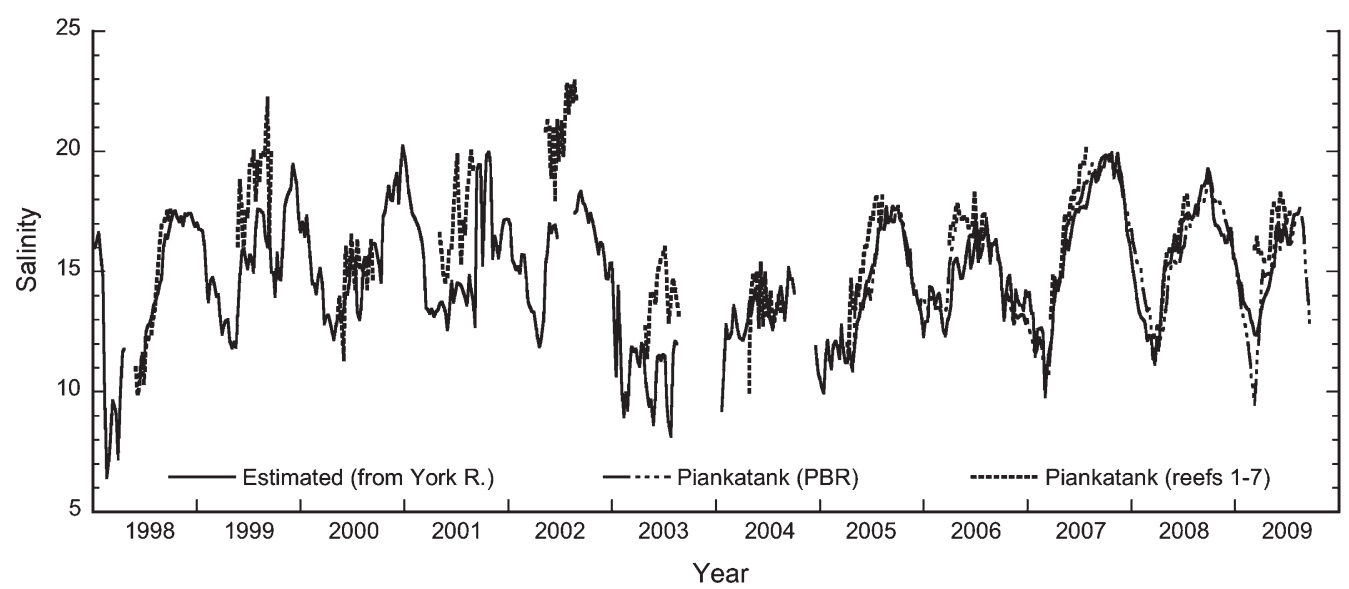

Figure 3. Average weekly bottom salinity in the Piankatank River, Virginia, as estimated from the York River (Virginia Institute of Marine Science, Gloucester Point, continuous, 2004-2009; solid line) and measured at Palace Bar Reef (PBR; continuous, 2005 to 2009) and all public reefs but Burton Point 2 (weekly averages, June to September 1998 to 2009; dotted line).

$37^{\circ} 14^{\prime} 47^{\prime \prime} \mathrm{N},-76^{\circ} 30^{\prime} 23^{\prime \prime} \mathrm{W}$; Fig. 1) were used to predict water temperatures at PBR prior to June 2005, when data are lacking from the Piankatank River but available for the York River.

Salinity data were collected commensurate with weekly water temperature data from June through September 1998 to 2009. From 1998 to 2004, salinity was measured with a handheld refractometer in water samples collected with a Niskin bottle $0.5 \mathrm{~m}$ from the bottom. From 2005 to 2009, weekly salinities were measured $0.5 \mathrm{~m}$ from the bottom with a handheld digital conductivity probe.

Linear regressions (Piankatank salinity $=\mathrm{b}+\mathrm{m} \times$ (York salinity)) were used to relate average daily salinity data from the York River at Gloucester Point and PBR in the Piankatank River for each month for June 2005 through 2009. These regressions were then used with measured average daily salinities from the York River at Gloucester Point from 1998 through December 2009 to predict the salinities in the Piankatank River.

\section{Oyster Field Collections}

Oysters were collected from the 43-ft long VMRC vessel J.B. Baylor with a hydraulic patent tong. The open dimensions of the tong were such that it sampled $1 \mathrm{~m}^{2}$ of bottom. Upon retrieval of each sample (= patent tong grab), oysters were counted and measured (in $\mathrm{mm}$ ), and the volume of shell material (in L) excluding oysters was recorded. The longest dimension from the hinge to the shell margin was measured for each oyster. This is correctly termed "shell height," although commonly described as shell length (SL) in most literature. We adopt the common convention and refer to SL in subsequent text. A count of the number of oysters per tong was made in all years sampled. From 1998 to 2002, all oysters were measured and classified into 5-mm size bins. Beginning in 2003, for each sample, individual oyster lengths were recorded to the nearest $\mathrm{mm}$. Samples with more than $20 \mathrm{~L}$ shell were halved to facilitate

TABLE 2.

Average oyster density (oysters $/ \mathrm{m}^{2}$ ) on the public reefs in the Piankatank River from 1998 to 2009.

\begin{tabular}{|c|c|c|c|c|c|c|c|c|c|c|c|c|c|}
\hline Reef & Area $\left(m^{2}\right)$ & 1998 & 1999 & 2000 & 2001 & 2002 & 2003 & 2004 & 2005 & 2006 & 2007 & 2008 & 2009 \\
\hline (1) Ginney Point & $2.43 \times 10^{4}$ & $\begin{array}{l}17.6^{7} \\
(5.1)\end{array}$ & $\begin{array}{l}189.3^{7} \\
(63.1)\end{array}$ & $\begin{array}{l}79.7^{7} \\
(26.5)\end{array}$ & $\begin{array}{l}46.0^{7} \\
(11.6)\end{array}$ & $\begin{array}{l}256.3^{7} \\
(25.0)\end{array}$ & $\begin{array}{l}26.9^{7} \\
(10.1)\end{array}$ & $\begin{array}{l}2.1^{7} \\
(0.8)\end{array}$ & $\begin{array}{l}1.3^{7} \\
(0.5)\end{array}$ & $\begin{array}{l}66.9^{7} \\
(17.5)\end{array}$ & $\begin{array}{l}145.9^{7} \\
(25.9)\end{array}$ & $\begin{array}{l}107.9^{7} \\
(24.9)\end{array}$ & $\begin{array}{l}44.1^{7} \\
(17.5)\end{array}$ \\
\hline (2) Palace Bar & $1.66 \times 10^{5}$ & $\begin{array}{l}112.1^{15} \\
(17.9)\end{array}$ & $\begin{array}{l}328.6^{7} \\
(71.2)\end{array}$ & $\begin{array}{l}98.8^{10} \\
(18.7)\end{array}$ & $\begin{array}{l}44.2^{10} \\
(6.0)\end{array}$ & $\begin{array}{l}235.7^{10} \\
(34.2)\end{array}$ & $\begin{array}{l}43.4^{10} \\
(5.8)\end{array}$ & $\begin{array}{l}11.1^{10} \\
(3.9)\end{array}$ & $\begin{array}{l}6.2^{10} \\
\left(1.7^{10}\right.\end{array}$ & $\begin{array}{l}70.3^{10} \\
(12.8)^{10}\end{array}$ & $\begin{array}{l}82.4^{10} \\
(14.9)\end{array}$ & $\begin{array}{c}106.7^{10} \\
(9.7)\end{array}$ & $\begin{array}{l}60.0^{10} \\
(11.1)^{10}\end{array}$ \\
\hline (3) Bland Point & $1.01 \times 10^{5}$ & $\begin{array}{l}59.6^{10} \\
(10.2)\end{array}$ & $\begin{array}{l}114.0^{7} \\
(41.0)\end{array}$ & $\begin{array}{l}53.0^{8} \\
(17.6)\end{array}$ & $\begin{array}{l}33.1^{10} \\
(7.1)\end{array}$ & $\begin{array}{l}188.9^{10} \\
(26.2)\end{array}$ & $\begin{array}{l}14.1^{10} \\
(4.1)\end{array}$ & $\begin{array}{l}5.9^{10} \\
(1.4)\end{array}$ & $\begin{array}{l}5.4^{10} \\
(1.8)\end{array}$ & $\begin{array}{l}36.5^{10} \\
(7.2)\end{array}$ & $\begin{array}{l}60.1^{10} \\
(14.0)\end{array}$ & $\begin{array}{l}55.2^{10} \\
(15.2)\end{array}$ & $\begin{array}{l}67.1^{10} \\
(16.2)\end{array}$ \\
\hline (4) Heron Rock & $5.04 \times 10^{4}$ & $\begin{array}{c}20.7^{7} \\
(10.3)\end{array}$ & $\begin{array}{l}236.4^{7} \\
(36.3)\end{array}$ & $\begin{array}{l}25.0^{7} \\
(11.4)\end{array}$ & $\begin{array}{l}20.0^{7} \\
(6.4)\end{array}$ & $\begin{array}{l}36.4^{7} \\
(20.2)\end{array}$ & $\begin{array}{l}9.9^{7} \\
(9.0)\end{array}$ & $\begin{array}{l}3.7^{7} \\
(1.7)\end{array}$ & $\begin{array}{l}1.6^{7} \\
(0.7)\end{array}$ & & $\begin{array}{l}34.9^{7} \\
(18.1)\end{array}$ & $\begin{array}{c}46.4^{7} \\
(19.0)\end{array}$ & $\begin{array}{l}34.4^{7} \\
(11.3)\end{array}$ \\
\hline (5) Cape Toon & $1.68 \times 10^{5}$ & $\begin{array}{l}15.3^{12} \\
(2.7)\end{array}$ & ND & $\begin{array}{l}29.1^{10} \\
(7.9)\end{array}$ & $\begin{array}{l}11.0^{10} \\
(3.0)\end{array}$ & $\begin{array}{l}50.0^{10} \\
(12.2)\end{array}$ & $\begin{array}{l}9.9^{10} \\
(2.8)\end{array}$ & $\begin{array}{l}2.8^{10} \\
(1.4)\end{array}$ & $\begin{array}{l}1.1^{8} \\
(0.6)\end{array}$ & & $\begin{array}{l}26.9^{10} \\
(3.9)\end{array}$ & $\begin{array}{l}21.6^{10} \\
(5.6)\end{array}$ & $\begin{array}{l}26.1^{10} \\
(5.9)\end{array}$ \\
\hline (6) Stove Point & $2.12 \times 10^{4}$ & $\begin{array}{l}47.4^{7} \\
(16.0)\end{array}$ & $\begin{array}{l}151.7^{7} \\
(58.0)\end{array}$ & $\begin{array}{l}41.0^{7} \\
(19.8)\end{array}$ & $\begin{array}{l}20.0^{7} \\
(7.2)\end{array}$ & $\begin{array}{l}269.9^{7} \\
(28.2)\end{array}$ & $\begin{array}{l}7.7^{7} \\
(2.9)\end{array}$ & $\begin{array}{l}1.0^{7} \\
(0.6)\end{array}$ & $\begin{array}{l}2.4^{7} \\
(0.9)\end{array}$ & $\begin{array}{l}21.6^{7} \\
(9.8)\end{array}$ & $\begin{array}{l}61.6^{7} \\
(15.9)\end{array}$ & $\begin{array}{l}19.1^{7} \\
(6.9)\end{array}$ & $\begin{array}{l}39.3^{7} \\
(9.4)\end{array}$ \\
\hline (7) Burton Point & $1.58 \times 10^{5}$ & $\begin{array}{l}19.9^{7} \\
(8.9)\end{array}$ & ND & $\begin{array}{l}16.0^{10} \\
(6.1)\end{array}$ & $\begin{array}{l}15.8^{10} \\
(3.5)\end{array}$ & $\begin{array}{l}40.2^{10} \\
(12.1)\end{array}$ & $\begin{array}{l}5.9^{10} \\
(2.9)\end{array}$ & $\begin{array}{l}0.9^{10} \\
(0.8)\end{array}$ & $\begin{array}{l}0.2^{10} \\
(0.1)\end{array}$ & $\begin{array}{l}12.1^{7} \\
(4.9)\end{array}$ & $\begin{array}{l}22.6^{7} \\
(10.9)\end{array}$ & $\begin{array}{c}35.4^{7} \\
(14.8)\end{array}$ & $\begin{array}{l}28.7^{7} \\
(8.1)\end{array}$ \\
\hline (8) Burton Point 2 & $3.07 \times 10^{4}$ & $\begin{array}{l}14.7^{14} \\
(3.6)\end{array}$ & $\begin{array}{l}37.1^{7} \\
(20.0)\end{array}$ & ND & $\begin{array}{l}10.3^{7} \\
(7.8)\end{array}$ & $\begin{array}{l}46.7^{7} \\
(21.9)\end{array}$ & $\begin{array}{l}21.1^{7} \\
(8.9)\end{array}$ & $\begin{array}{l}1.1^{7} \\
(1.0)\end{array}$ & $\begin{array}{l}1.3^{7} \\
(1.1)\end{array}$ & $\begin{array}{l}15.1^{7} \\
(7.5)\end{array}$ & $\begin{array}{l}12.6^{7} \\
(7.7)\end{array}$ & $\begin{array}{l}12.6^{7} \\
(6.6)\end{array}$ & $\begin{array}{l}1.9^{7} \\
(1.9)\end{array}$ \\
\hline
\end{tabular}

Data are presented as the average number of oysters $/ \mathrm{m}^{2}$ (Standard errors of the mean are in parentheses and $n$ values are a superscript for each mean value). $\mathrm{ND}=$ data were not available for a particular reef/year. The identification numbers for the individual reefs correspond to those used in Figure 1. 
TABLE 3.

Average oyster biomass (in grams dry tissue weight) on the public reefs in the Piankatank River from 1998 to 2009.

\begin{tabular}{|c|c|c|c|c|c|c|c|c|c|c|c|c|c|}
\hline Reef & Area $\left(m^{2}\right)$ & 1998 & 1999 & 2000 & 2001 & 2002 & 2003 & 2004 & 2005 & 2006 & 2007 & 2008 & 2009 \\
\hline (1) Ginney Point & $2.43 \times 10^{4}$ & $\begin{array}{c}3.7^{7} \\
(1.1)\end{array}$ & & & & & $\begin{array}{c}8.8^{7} \\
(3.8)\end{array}$ & & $\begin{array}{c}0.3^{7} \\
(0.1)\end{array}$ & & & & $\begin{array}{c}23.7^{7} \\
(10.5)\end{array}$ \\
\hline (2) Palace Bar & $1.66 \times 10^{5}$ & $\begin{array}{l}20.0^{15} \\
(3.6)\end{array}$ & $\begin{array}{l}20.0^{7} \\
(4.1)\end{array}$ & $\begin{array}{l}13.2^{10} \\
(3.2)\end{array}$ & $\begin{array}{l}12.1^{10} \\
(1.6)\end{array}$ & $\begin{array}{l}20.7^{10} \\
(3.2)\end{array}$ & $\begin{array}{l}12.7^{10} \\
(2.2)\end{array}$ & $\begin{array}{l}5.0^{10} \\
(1.8)\end{array}$ & $\begin{array}{l}2.7^{10} \\
(0.9)\end{array}$ & $\begin{array}{l}14.5^{10} \\
(2.9)\end{array}$ & $\begin{array}{l}20.1^{10} \\
(3.9)\end{array}$ & $\begin{array}{l}21.6^{10} \\
(3.3)\end{array}$ & $\begin{array}{l}19.8^{10} \\
(5.0)\end{array}$ \\
\hline (3) Bland Point & $1.01 \times 10^{5}$ & $\begin{array}{l}13.0^{10} \\
(4.6)\end{array}$ & $\begin{array}{l}10.5^{7} \\
(3.9)\end{array}$ & $\begin{array}{l}7.6^{8} \\
(3.2)\end{array}$ & $\begin{array}{c}9.5^{10} \\
(2.5)\end{array}$ & $\begin{array}{l}23.3^{10} \\
(4.2)\end{array}$ & $\begin{array}{c}4.1^{10} \\
(1.5)\end{array}$ & $\begin{array}{l}2.3^{10} \\
(0.6)\end{array}$ & $\begin{array}{l}2.5^{10} \\
(1.1)\end{array}$ & $\begin{array}{l}8.3^{10} \\
(2.1)\end{array}$ & $\begin{array}{l}16.3^{10} \\
(4.1)\end{array}$ & $\begin{array}{l}13.4^{10} \\
(4.1)^{10}\end{array}$ & $\begin{array}{l}25.6^{10} \\
(8.2)\end{array}$ \\
\hline (4) Heron Rock & $5.04 \times 10^{4}$ & $\begin{array}{l}5.5^{7} \\
(3.7)\end{array}$ & $\begin{array}{l}17.1^{7} \\
(3.4)\end{array}$ & $\begin{array}{c}7.1^{7} \\
(3.4)\end{array}$ & $\begin{array}{c}3.9^{7} \\
(1.2)\end{array}$ & $\begin{array}{c}4.5^{7} \\
(2.3)\end{array}$ & $\begin{array}{c}3.1^{7} \\
(2.8)\end{array}$ & $\begin{array}{c}2.1^{7} \\
(1.0)\end{array}$ & $\begin{array}{c}0.1^{7} \\
(0.1)^{2}\end{array}$ & $\begin{array}{c}3.0^{7} \\
(1.4)\end{array}$ & $\begin{array}{l}10.3^{7} \\
(6.0)\end{array}$ & $\begin{array}{c}8.7^{7} \\
(4.6)\end{array}$ & $\begin{array}{l}13.4^{7} \\
(4.2)\end{array}$ \\
\hline (5) Cape Toon & $1.68 \times 10^{5}$ & $\begin{array}{l}2.7^{12} \\
(0.7)\end{array}$ & ND & $\begin{array}{l}6.8^{10} \\
(2.5)\end{array}$ & & & $\begin{array}{l}3.0^{10} \\
(0.8)\end{array}$ & $\begin{array}{l}1.6^{10} \\
(0.9)\end{array}$ & $\begin{array}{c}0.4^{8} \\
(0.4)\end{array}$ & $\begin{array}{l}3.7^{10} \\
(0.7)\end{array}$ & $\begin{array}{l}6.7^{10} \\
(1.2)\end{array}$ & $\begin{array}{c}7.5^{10} \\
(1.9)\end{array}$ & $\begin{array}{l}11.2^{10} \\
(2.5)\end{array}$ \\
\hline (6) Stove Point & $2.12 \times 10^{4}$ & $\begin{array}{l}9.8^{7} \\
(3.3)\end{array}$ & $\begin{array}{c}22.1^{7} \\
(9.0)\end{array}$ & $\begin{array}{l}12.7^{7} \\
(6.3)\end{array}$ & & $\begin{array}{l}22.6^{7} \\
(1.7)\end{array}$ & $\begin{array}{l}2.2^{7} \\
(0.8)\end{array}$ & $\begin{array}{l}0.3^{7} \\
(0.2)\end{array}$ & $\begin{array}{c}0.7^{7} \\
(0.3)\end{array}$ & $\begin{array}{c}3.7^{7} \\
(1.8)\end{array}$ & $\begin{array}{l}16.9^{7} \\
(4.6)\end{array}$ & & $\begin{array}{l}21.0^{7} \\
(6.6)\end{array}$ \\
\hline (7) Burton Point & $1.58 \times 10^{5}$ & $\begin{array}{c}3.3^{7} \\
(1.5)\end{array}$ & ND & $\begin{array}{l}3.2^{10} \\
(1.3)\end{array}$ & $\begin{array}{l}3.7^{10} \\
(0.9)\end{array}$ & $\begin{array}{l}3.2^{10} \\
(1.1)\end{array}$ & $\begin{array}{l}1.5^{10} \\
(0.8)\end{array}$ & $\begin{array}{l}0.6^{10} \\
(0.4)\end{array}$ & $\begin{array}{l}0.1^{10} \\
(0.1)\end{array}$ & $\begin{array}{l}1.9^{7} \\
(0.7)\end{array}$ & $\begin{array}{l}5.5^{7} \\
(2.7)\end{array}$ & $\begin{array}{l}14.2^{7} \\
(6.1)\end{array}$ & $\begin{array}{l}12.8^{7} \\
(4.4)\end{array}$ \\
\hline (8) Burton Point 2 & $3.07 \times 10^{4}$ & $\begin{array}{l}2.4^{14} \\
(0.6)\end{array}$ & $\begin{array}{l}3.9^{7} \\
(2.3)\end{array}$ & ND & $\begin{array}{c}4.1^{7} \\
(3.0)\end{array}$ & $\begin{array}{c}4.1^{7} \\
(1.8)\end{array}$ & $\begin{array}{c}7.0^{7} \\
(3.1)\end{array}$ & $\begin{array}{c}0.6^{7} \\
(0.5)\end{array}$ & $\begin{array}{c}0.8^{7} \\
(0.8)\end{array}$ & $\begin{array}{c}2.8^{7} \\
(1.6)\end{array}$ & $\begin{array}{l}2.8^{7} \\
(1.9)\end{array}$ & $\begin{array}{c}3.7^{7} \\
(2.1)\end{array}$ & $\begin{array}{c}0.6^{7} \\
(0.6)\end{array}$ \\
\hline
\end{tabular}

Data are presented as average biomass ( $g$ dry tissue weight $/ \mathrm{m}^{2}$ ) (Standard errors of the mean are in parentheses and $n$ values are a superscript for each mean value). $\mathrm{ND}=$ data not available for a particular reef/year. The identification numbers for the individual reefs correspond to those used in Figure 1.

processing. The resulting counts and length frequency distributions for the subsample were doubled to estimate density and size distribution on a per- $\mathrm{m}^{2}$ basis when subsampling was necessary. The procedures of Bros and Cowell (1987) were used to ensure adequacy of sampling within each strata.

Average oyster density (number $/ \mathrm{m}^{2}$ ) was calculated for each oyster reef by averaging the number of oysters collected from all samples on a reef within a year. Average shell volume $\left(\mathrm{L} / \mathrm{m}^{2}\right)$ was calculated by averaging the total volume of shell collected from all samples on a reef within a year. For the period 2002 to 2009 , shell was additionally categorized as brown shell, which is shell that lies above the sediment water interface, and black shell that was exhumed from below the surface during the collection process.

TABLE 4.

Summary of statistical analyses for Piankatank River public oyster reefs.

\begin{tabular}{|c|c|c|c|c|c|c|c|}
\hline Test & Response & Covariate & Factor & df & Test Statistic & $P$ Value & Multiple Comparison $\dagger$ \\
\hline \multirow[t]{2}{*}{ ANOVA } & Total shell volume & & Reef & 7 & 12.03 & $<0.01 *$ & $2>4,6,8 ;$ all other reefs $>8$ \\
\hline & & & Year & 11 & 3.15 & $<0.01^{*}$ & $2002>1998,2001,2003-2009$ \\
\hline \multirow[t]{2}{*}{ ANOVA } & Brown shell volume & & Reef & 7 & 10.08 & $<0.01^{*}$ & $1>4,5,7,8 ; 2,3,6,>5,8$ \\
\hline & & & Year & 7 & 1.93 & 0.06 & \\
\hline \multirow[t]{3}{*}{ ANCOVA } & Log density & Total shell volume & & 1 & 299.03 & $<0.01^{*}$ & \\
\hline & & & Reef & 7 & 13.82 & $<0.01^{*}$ & $2,3>4,5,6,7,8$ \\
\hline & & & Year & 11 & 51.77 & $<0.01^{*}$ & $\begin{aligned} 1999,2002 & >1998,2001 \\
2006-2009 & >2003-2005\end{aligned}$ \\
\hline \multirow[t]{3}{*}{ ANCOVA } & Log biomass & Total shell volume & & 1 & 249.72 & $<0.01^{*}$ & \\
\hline & & & Reef & 7 & 7.73 & $<0.01^{*}$ & $2,3>4,5,7,8$ \\
\hline & & & Year & 11 & 24.79 & $<0.01^{*}$ & $\begin{array}{l}\text { All other years }>2005,1999-2000 \\
\text { and } 2007-2009>2003-2004\end{array}$ \\
\hline \multirow[t]{3}{*}{ ANCOVA } & Log density & Brown shell volume & & 1 & 228.82 & $<0.01^{*}$ & \\
\hline & & & Reef & 7 & 7.17 & $<0.01^{*}$ & $2>4,5,7,8$ \\
\hline & & & Year & 7 & 81.03 & $<0.01 *$ & $2002>2006-2009>2003>2004-2005$ \\
\hline \multirow[t]{3}{*}{ ANCOVA } & Log biomass & Brown shell volume & & 1 & 196.91 & $<0.01 *$ & \\
\hline & & & Reef & 7 & 3.43 & $<0.01^{*}$ & $1,2,3>4$ \\
\hline & & & Year & 7 & 40.31 & $<0.01^{*}$ & $\begin{array}{l}2002,2007-2009>2003-2004>2005, \\
\text { all other years }>2005\end{array}$ \\
\hline
\end{tabular}

Multiple comparison results refer to the reef numbers in Table 1 and Figure 1.

$\dagger$ Numbers 1-8 correspond to reefs (1) Ginney Point, (2) Palace Bar, (3) Bland Point, (4) Heron Rock, (5) Cape Toon, (6) Stove Point, (7) Burton Point, and (8) Burton Point 2 as in Figure 1.

* = Statistically significant $P$ values.

$\log =\log$-transformed data as discussed in text. 
TABLE 5.

Average total volume of oyster shell $\left(\mathrm{L} / \mathrm{m}^{2}\right)$ on the reefs in the Piankatank River from 1998 to 2009.

\begin{tabular}{|c|c|c|c|c|c|c|c|c|c|c|c|c|c|}
\hline Reef & Area $\left(m^{2}\right)$ & 1998 & 1999 & 2000 & 2001 & 2002 & 2003 & 2004 & 2005 & 2006 & 2007 & 2008 & 2009 \\
\hline (1) Ginney Point & $2.43 \times 10^{4}$ & $\begin{array}{l}8.0^{7} \\
(0.9)\end{array}$ & $\begin{array}{l}11.4^{7} \\
(2.0)\end{array}$ & $\begin{array}{l}8.4^{7} \\
(2.6)\end{array}$ & $\begin{array}{l}13.6^{7} \\
(3.9)\end{array}$ & $\begin{array}{l}18.3^{7} \\
(1.8)\end{array}$ & $\begin{array}{l}12.4^{7} \\
(3.0)\end{array}$ & $\begin{array}{c}9.5^{7} \\
(1.5)\end{array}$ & $\begin{array}{l}9.3^{7} \\
(2.8)\end{array}$ & $\begin{array}{l}17.4^{7} \\
(3.1)\end{array}$ & $\begin{array}{l}17.7^{7} \\
(2.8)\end{array}$ & $\begin{array}{l}17.0^{7} \\
(3.1)\end{array}$ & $\begin{array}{l}10.0^{7} \\
(1.8)\end{array}$ \\
\hline (2) Palace Bar & $1.66 \times 10^{5}$ & $\begin{array}{l}17.9^{15} \\
(1.8)\end{array}$ & $\begin{array}{l}20.6^{7} \\
(3.0)\end{array}$ & $\begin{array}{l}11.7^{10} \\
(1.9)\end{array}$ & $\begin{array}{l}16.9^{10} \\
(2.0)\end{array}$ & $\begin{array}{l}20.5^{10} \\
(2.0)\end{array}$ & $\begin{array}{l}14.1^{10} \\
(1.9)^{10}\end{array}$ & $\begin{array}{l}16.4^{10} \\
(2.5)\end{array}$ & $\begin{array}{l}14.5^{10} \\
(2.1)^{10}\end{array}$ & $\begin{array}{l}17.1^{10} \\
(1.5)\end{array}$ & $\begin{array}{l}14.1^{10} \\
(1.2)\end{array}$ & $\begin{array}{l}18.7^{10} \\
(2.4)\end{array}$ & $\begin{array}{l}12.2^{10} \\
(1.7)\end{array}$ \\
\hline (3) Bland Point & $1.01 \times 10^{5}$ & $\begin{array}{l}16.6^{10} \\
(2.1)\end{array}$ & $\begin{array}{l}11.0^{7} \\
(3.4)\end{array}$ & $\begin{array}{l}9.1^{8} \\
(2.7)\end{array}$ & $\begin{array}{l}11.7^{10} \\
(3.1)\end{array}$ & $\begin{array}{l}22.0^{10} \\
(3.2)\end{array}$ & $\begin{array}{l}12.3^{10} \\
(2.2)\end{array}$ & $\begin{array}{l}11.0^{10} \\
(2.4)\end{array}$ & $\begin{array}{l}11.1^{10} \\
(2.8)\end{array}$ & $\begin{array}{l}14.3^{10} \\
(2.1)\end{array}$ & $\begin{array}{l}12.1^{10} \\
(1.9)\end{array}$ & $\begin{array}{l}9.8^{10} \\
(1.7)\end{array}$ & $\begin{array}{l}12.3^{10} \\
(2.3)\end{array}$ \\
\hline (4) Heron Rock & $5.04 \times 10^{4}$ & $\begin{array}{c}6.8^{7} \\
(3.0)\end{array}$ & $\begin{array}{l}16.0^{7} \\
(2.0)\end{array}$ & $\begin{array}{c}6.9^{7} \\
(3.0)\end{array}$ & $\begin{array}{l}7.7^{7} \\
(2.5)\end{array}$ & $\begin{array}{l}9.9^{7} \\
(3.5)\end{array}$ & $\begin{array}{l}9.9^{7} \\
(3.6)\end{array}$ & $\begin{array}{l}6.3^{7} \\
(2.6)\end{array}$ & $\begin{array}{c}4.6^{7} \\
(1.7)\end{array}$ & $\begin{array}{c}6.4^{7} \\
(1.8)\end{array}$ & $\begin{array}{l}9.4^{7} \\
(2.2)\end{array}$ & $\begin{array}{l}10.5^{7} \\
(2.9)\end{array}$ & $\begin{array}{l}12.9^{7} \\
(2.7)\end{array}$ \\
\hline (5) Cape Toon & $1.68 \times 10^{5}$ & $\begin{array}{l}14.0^{12} \\
(3.3)\end{array}$ & ND & $\begin{array}{l}12.9^{10} \\
(2.7)^{10}\end{array}$ & $\begin{array}{l}9.5^{10} \\
(2.2)\end{array}$ & $\begin{array}{l}16.5^{10} \\
(1.7)^{10}\end{array}$ & $\begin{array}{l}10.5^{10} \\
(1.9)\end{array}$ & $\begin{array}{c}9.1^{10} \\
(1.9)\end{array}$ & $\begin{array}{l}7.5^{8} \\
(1.2)\end{array}$ & $\begin{array}{l}7.4^{10} \\
(1.2)\end{array}$ & $\begin{array}{l}7.6^{10} \\
(1.3)\end{array}$ & $\begin{array}{l}10.2^{10} \\
(1.8)\end{array}$ & $\begin{array}{l}12.4^{10} \\
(2.6)\end{array}$ \\
\hline (6) Stove Point & $2.12 \times 10^{4}$ & $\begin{array}{l}13.3^{7} \\
(2.9)\end{array}$ & $\begin{array}{l}12.6^{7} \\
(2.3)\end{array}$ & $\begin{array}{c}9.7^{7} \\
(4.6)\end{array}$ & $\begin{array}{r}5.1^{7} \\
(1.3)\end{array}$ & $\begin{array}{l}13.1^{7} \\
(1.7)\end{array}$ & $\begin{array}{c}6.2^{7} \\
(3.1)\end{array}$ & $\begin{array}{c}5.6^{7} \\
(2.9)\end{array}$ & $\begin{array}{c}9.9^{7} \\
(3.5)\end{array}$ & $\begin{array}{l}9.0^{7} \\
(3.2)\end{array}$ & $\begin{array}{l}13.2^{7} \\
(2.1)\end{array}$ & $\begin{array}{l}5.2^{7} \\
(2.6)\end{array}$ & $\begin{array}{l}15.1^{7} \\
(2.5)\end{array}$ \\
\hline (7) Burton Point & $1.58 \times 10^{5}$ & $\begin{array}{l}10.9^{7} \\
(4.0)\end{array}$ & $\mathrm{ND}$ & $\begin{array}{l}7.5^{10} \\
(2.4)\end{array}$ & $\begin{array}{l}12.4^{10} \\
(2.3)\end{array}$ & $\begin{array}{l}15.4^{10} \\
(1.7)\end{array}$ & $\begin{array}{l}10.1^{10} \\
(2.4)\end{array}$ & $\begin{array}{l}1.7^{10} \\
(0.8)\end{array}$ & $\begin{array}{l}3.8^{10} \\
(1.2)\end{array}$ & $\begin{array}{r}5.0^{7} \\
(1.7)\end{array}$ & $\begin{array}{l}11.1^{7} \\
(4.6)\end{array}$ & $\begin{array}{c}9.9^{7} \\
(3.8)\end{array}$ & $\begin{array}{l}16.4^{7} \\
(1.7)\end{array}$ \\
\hline (8) Burton Point 2 & $3.07 \times 10^{4}$ & $\begin{array}{l}6.1^{14} \\
(0.8)\end{array}$ & $\begin{array}{l}5.1^{7} \\
(1.5)\end{array}$ & ND & $\begin{array}{l}3.2^{7} \\
(2.1)\end{array}$ & $\begin{array}{l}6.0^{7} \\
(2.3)\end{array}$ & $\begin{array}{c}8.6^{7} \\
(1.9)\end{array}$ & $\begin{array}{l}2.0^{7} \\
(1.2)\end{array}$ & $\begin{array}{l}4.5^{7} \\
(1.9)\end{array}$ & $\begin{array}{l}4.5^{7} \\
(2.2)\end{array}$ & $\begin{array}{l}4.8^{7} \\
(1.3)\end{array}$ & $\begin{array}{c}3.2^{7} \\
(1.2)\end{array}$ & $\begin{array}{l}6.5^{7} \\
(2.5)\end{array}$ \\
\hline
\end{tabular}

Data are presented as average total shell volume $/ \mathrm{m}^{2}$ (Standard errors of the mean are in parentheses and $n$ values are a superscript for each mean value). $\mathrm{ND}=$ data not available for a particular reef/year.

\section{Biomass Estimation}

Data from a size range (SL, 26-109 mm) of live oysters $(n=$ 651) collected from the Piankatank River in November 2004 through 2009 were used to estimate the relationship between oyster shell length (in $\mathrm{mm}$ ) and biomass or dry tissue weight (in g) on public oyster reefs. After oyster SL was measured to the nearest $\mathrm{mm}$, the tissue was removed and dried to constant weight (dry tissue weight in $\mathrm{g}$ ) at $80^{\circ} \mathrm{C}(72 \mathrm{~h})$.

Wet shell weight (WSW in $\mathrm{g}$ ) was obtained from the same 651 oysters used for biomass estimation after the tissue had been removed and before the shells had dried. The relationship between SL and WSW was described. Biomass and shell weight calculations were made for each reef using the midpoint of each reef-specific, 5-mm size class as $\mathrm{SL}$ in the fitted SL-DW equation and are reported for 1998 to 2009.

\section{Age Structure and Mortality}

The estimation of age structure from length demographic plots follows the procedure in Harding et al. (2008), Mann et al. (2009b), and Southworth et al. (2010b). Briefly, demographic plots were prepared for each year (2003 to 2009) for the live oysters ( $n=13,349$ oysters), measured from each reef where live oysters were aggregated, on a year-specific length frequency graph using 2-mm-length bins. Individual cohorts were identified by the method of Bhattacharya (1967). The range and modal length of each cohort was identified by counting cohorts and

TABLE 6.

Average volume of brown oyster shell $\left(\mathrm{L} / \mathrm{m}^{2}\right)$ on the reefs in the Piankatank River from 1998 to 2009.

\begin{tabular}{|c|c|c|c|c|c|c|c|c|c|}
\hline Reef & Area $\left(m^{2}\right)$ & 2002 & 2003 & 2004 & 2005 & 2006 & 2007 & 2008 & 2009 \\
\hline (1) Ginney Point & $2.43 \times 10^{4}$ & $15.7^{7}$ & $9.3^{7}$ & $\begin{array}{l}7.3^{7} \\
(0.8)\end{array}$ & $7.7^{7}$ & $14.9^{7}$ & $14.9^{7}$ & $13.3^{7}$ & $7.0^{7}$ \\
\hline (2) Palace Bar & $1.66 \times 10^{5}$ & $\begin{array}{l}12.0^{10} \\
(0.7)\end{array}$ & $\begin{array}{l}10.7^{10} \\
(0.5)\end{array}$ & $\begin{array}{l}11.4^{10} \\
(0.7)\end{array}$ & $\begin{array}{l}9.4^{10} \\
(0.6)\end{array}$ & $\begin{array}{l}13.1^{10} \\
(0.6)\end{array}$ & $\begin{array}{l}8.5^{10} \\
(0.4)\end{array}$ & $\begin{array}{l}11.0^{10} \\
(0.9)\end{array}$ & $\begin{array}{c}5.8^{10} \\
(0.4)\end{array}$ \\
\hline (3) Bland Point & $1.01 \times 10^{5}$ & $\begin{array}{l}14.6^{10} \\
(0.9)\end{array}$ & $\begin{array}{l}3.9^{10} \\
(0.3)\end{array}$ & $\begin{array}{l}9.0^{10} \\
(0.7)\end{array}$ & $\begin{array}{l}8.6^{10} \\
(0.8)\end{array}$ & $\begin{array}{l}8.6^{10} \\
(0.7)\end{array}$ & $\begin{array}{l}6.5^{10} \\
(0.5)\end{array}$ & $\begin{array}{l}5.5^{10} \\
(0.4)\end{array}$ & $\begin{array}{l}8.9^{10} \\
(0.7)\end{array}$ \\
\hline (4) Heron Rock & $5.04 \times 10^{4}$ & $\begin{array}{c}6.0^{7} \\
(1.1)\end{array}$ & $\begin{array}{c}4.1^{7} \\
(1.4)\end{array}$ & $\begin{array}{l}3.2^{7} \\
(0.6)\end{array}$ & $\begin{array}{l}1.9^{7} \\
(0.4)\end{array}$ & $\begin{array}{l}3.0^{7} \\
(0.4)\end{array}$ & $\begin{array}{c}4.4^{7} \\
(0.7)\end{array}$ & $\begin{array}{c}6.8^{7} \\
(1.0)\end{array}$ & $\begin{array}{l}7.6^{7} \\
(0.9)\end{array}$ \\
\hline (5) Cape Toon & $1.68 \times 10^{5}$ & $\begin{array}{l}6.8^{10} \\
(0.5)\end{array}$ & $\begin{array}{l}3.3^{10} \\
(0.3)\end{array}$ & $\begin{array}{l}1.7^{10} \\
(0.2)\end{array}$ & $\begin{array}{l}3.3^{8} \\
(0.3)\end{array}$ & $\begin{array}{l}4.8^{10} \\
(0.3)\end{array}$ & $\begin{array}{l}2.6^{10} \\
(0.1)\end{array}$ & $\begin{array}{l}4.3^{10} \\
(0.3)\end{array}$ & $\begin{array}{l}6.6^{10} \\
(0.6)\end{array}$ \\
\hline (6) Stove Point & $2.12 \times 10^{4}$ & $\begin{array}{l}10.9^{7} \\
(0.3)\end{array}$ & $\begin{array}{c}4.8^{7} \\
(1.2)\end{array}$ & $\begin{array}{c}3.9^{7} \\
(1.0)\end{array}$ & $\begin{array}{c}8.9^{7} \\
(1.3)\end{array}$ & $\begin{array}{c}7.3^{7} \\
(1.2)\end{array}$ & $\begin{array}{l}9.3^{7} \\
(0.8)\end{array}$ & $\begin{array}{l}4.3^{7} \\
(0.8)\end{array}$ & $\begin{array}{l}10.4^{7} \\
(0.9)\end{array}$ \\
\hline (7) Burton Point & $1.58 \times 10^{5}$ & $\begin{array}{l}3.2^{10} \\
(0.2)\end{array}$ & $\begin{array}{l}1.9^{10} \\
(0.2)\end{array}$ & $\begin{array}{l}0.7^{10} \\
(0.1)^{10}\end{array}$ & $\begin{array}{l}1.3^{10} \\
(0.1)\end{array}$ & $\begin{array}{l}3.4^{7} \\
(0.5)\end{array}$ & $\begin{array}{c}6.7^{7} \\
(1.7)\end{array}$ & $\begin{array}{l}6.0^{7} \\
(0.9)\end{array}$ & $\begin{array}{l}11.0^{7} \\
(1.1)\end{array}$ \\
\hline (8) Burton Point 2 & $3.07 \times 10^{4}$ & $\begin{array}{l}3.3^{7} \\
(0.7)\end{array}$ & $\begin{array}{c}4.3^{7} \\
(0.7)\end{array}$ & $\begin{array}{c}0.6^{7} \\
(0.2)\end{array}$ & $\begin{array}{l}2.0^{7} \\
(0.4)\end{array}$ & $\begin{array}{l}3.6^{7} \\
(0.6)\end{array}$ & $\begin{array}{l}1.8^{7} \\
(0.4)\end{array}$ & $\begin{array}{l}1.5^{7} \\
(0.3)\end{array}$ & $\begin{array}{l}0.8^{7} \\
(0.3)\end{array}$ \\
\hline
\end{tabular}

Data are presented as average brown shell volume $/ \mathrm{m}^{2}$ (Standard errors of the mean are in parentheses and $n$ values are a superscript for each mean value). 
relating the cohort settlement dates to long-term recruitment patterns developed from annual recruitment (spatfall) reports for the Piankatank River over the study period (Southworth et al. 1999, 2000, 2001, 2002, 2003, 2004, 2005, 2006, 2007, 2008, 2009, 2010a (available at http://www.vims.edu/mollusc)). The quadratic relationship $\left(\mathrm{SL}=\mathrm{a} \times(\text { Age })^{2}+\mathrm{b} \times(\right.$ Age $\left.)+\mathrm{c}\right)$ was used to describe the age-length relationship, because it provides higher values for the coefficient of determination and a more accurate fit for the older age classes than a corresponding linear model. The demographic plots were recast as graphs of year classes for each year by location in the river for 1998 through 2009 using the quadratic relationship for all years.

Annual mortality, as a proportion of the standing population, was estimated by the following relationship:

$$
\text { Mortality }=[\# \operatorname{Live}(\mathrm{t})-\# \operatorname{Live}(\mathrm{t}+1) / \# \operatorname{Live}(\mathrm{t})]
$$

where \#Live(t) equals the number of live oysters at time $\mathrm{t}(\mathrm{t}$, units of $1 \mathrm{y}$ ). Possible errors in this approach are discussed in Mann et al. (2009b).

\section{Disease Status}

The prevalence and intensity of Perkinsus marinus (Dermo) and H. nelsoni (MSX) at selected locations in the study area are reported by Ragone Calvo \& Burreson (1999, 2000, 2001, 2002, 2003), Carnegie et al. (2004), and Carnegie \& Burreson (2005, 2006, 2009). Disease data are presented herein as either prevalence (percent infected) or weighted prevalence (WP) for comparison with mortality data. WP is calculated based on the following formula from Burreson et al. (1988):

$$
\mathrm{WP}=(0.5 \times \mathrm{R})+(1 \times \mathrm{L})+(3 \times \mathrm{M})+(5 \times \mathrm{H}) / n
$$

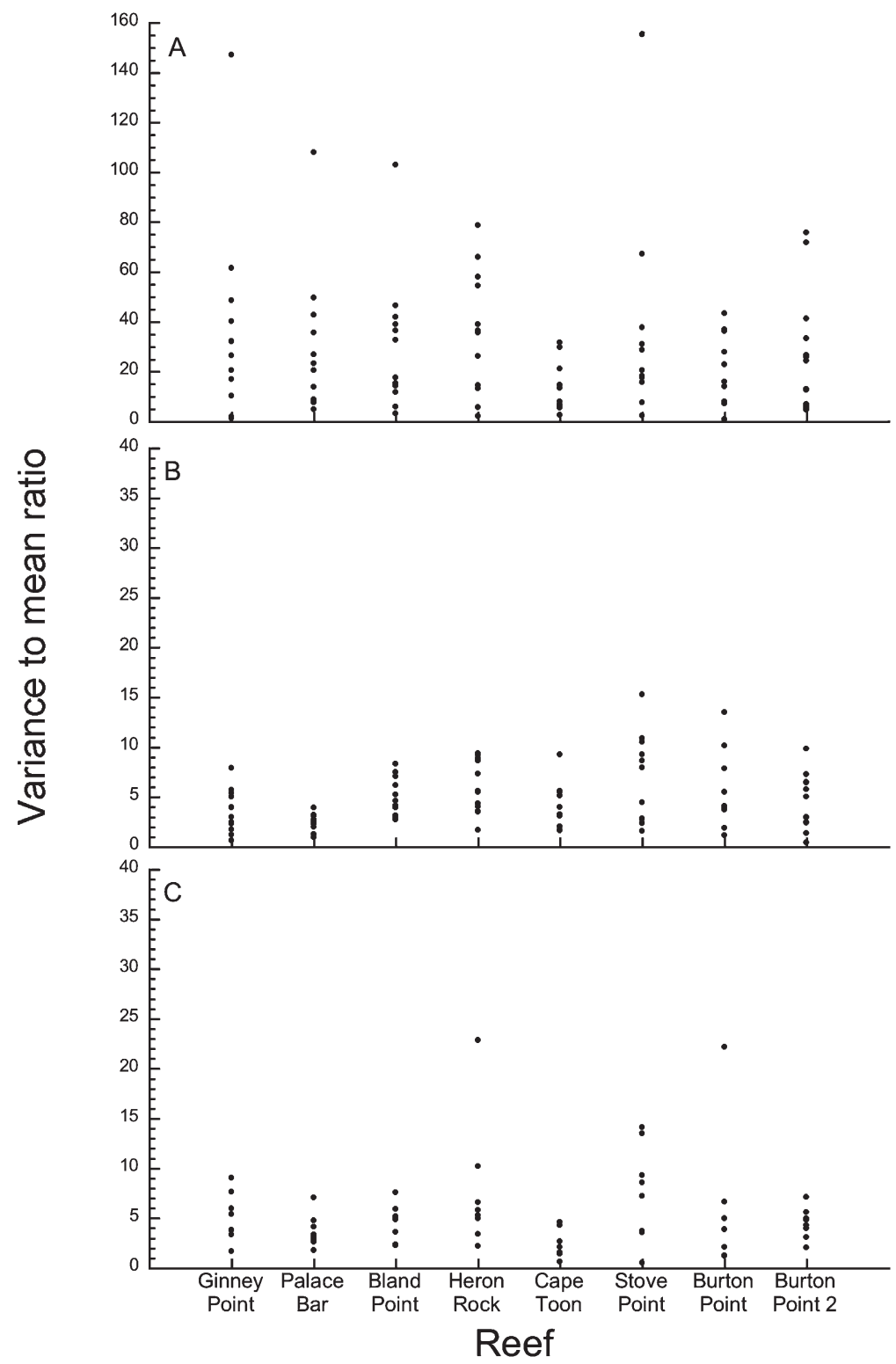

Figure 4. (A-C) Variance-to-mean ratios from replicate samples on the same reef of oyster density (A; 1998 to 2009), total shell volume (B; 1998 to 2009), and brown shell volume (C; 2002 to 2009) for the 8 public reefs in the Piankatank River. 
HARDING ET AL.
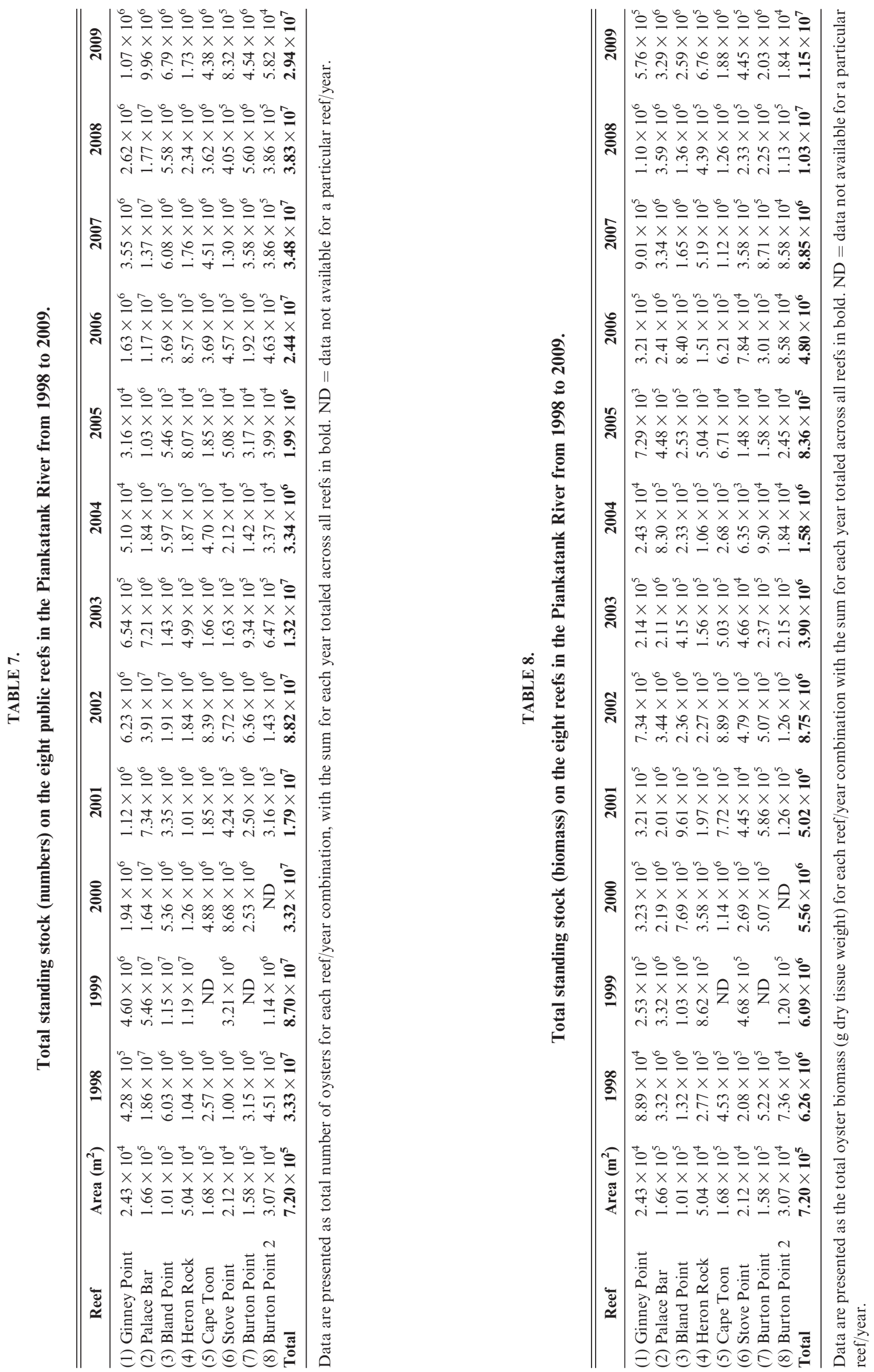
where $\mathrm{R}, \mathrm{L}, \mathrm{M}$, and $\mathrm{H}$ are rare, light, medium, and heavy infection intensity, respectively, and $n$ is the total number of oysters tested. Disease samples are typically taken from oysters with an SL greater than $60 \mathrm{~mm}$.

\section{Data Analyses}

Seven hundred seventy-eight data pairs (total shell volume, live oyster density) including patent tong grabs with total volume $=0$ and/or density $=0$ were used to describe the relationship between the presence of oyster shell and live oysters on public reefs in the Piankatank River (1998 to 2009) with a linear model:

Live oyster density $=-7.6142+5.1372($ total shell volume,

$$
\left.\mathrm{L} / \mathrm{m}^{2}\right) ; n=778 \text { tongs, } R^{2}=0.28
$$

The negative y-intercept describes the prerequisite for oyster shell (habitat) for the success of live oysters. All subsequent analyses include only tongs with a total shell volume greater than 0 and a density of live oysters greater than $0(n=675$ tongs with non-0 total volume and density).

The relationship between brown shell volume (in $\mathrm{L} / \mathrm{m}^{2}$ ) and total shell volume (in $\mathrm{L} / \mathrm{m}^{2}$ ) was described using a linear model to examine 530 data pairs:

$$
\begin{aligned}
& \text { Brown shell volume }\left(\mathrm{L} / \mathrm{m}^{2}\right)=-1.3152+0.7203 \\
& \quad \times\left(\text { total shell volume }, \mathrm{L} / \mathrm{m}^{2}\right) ; R^{2}=0.70
\end{aligned}
$$

The negative intercept is indicative of a minimum basal or spatial footprint requirement of total shell volume to provide some brown shell (habitat) at the substrate-water interface. A minimum of approximately $2 \mathrm{~L} / \mathrm{m}^{2}$ total shell volume is required to provide any positive value of brown shell volume. The coefficient of determination indicates that brown shell volume is a predictor of the total shell volume a majority of the time on the public reefs in the Piankatank River.

The relationship between brown shell volume $\left(\mathrm{L} / \mathrm{m}^{2}\right)$ and oyster density on Piankatank River public reefs (2002 to 2009) was also described with a linear model:

Live oyster density $=8.8794+5.3794$ (brown shell volume,

$\left.\mathrm{L} / \mathrm{m}^{2}\right), n=455$ tongs; $R^{2}=0.26$
The y-intercept value for the brown shell volume-oyster density relationship is higher than that observed for the total shell volume-density relationship, indicating that brown shell volume is a requirement for oyster habitat. The relatively low coefficient of determination for the brown shell-density relationship may be the result of relatively low oyster densities (discussed later) or patchiness in the spatial distribution of the live oyster resource (discussed later). Only tongs with a total volume greater than 0 and a live oyster density more than $0(n=$ 615 for total volume, $n=409$ for brown shell volume) were used for subsequent analyses.

The relationship between oyster SL (in $\mathrm{mm}$ ) and oyster biomass (g dry tissue) for 651 oysters ranging from 26-109 mm in SL was described using a power equation:

$$
\operatorname{Biomass}(\mathrm{g})=4.9216 \times 10^{-5} \times \mathrm{SL}^{(2.2995)} ; R^{2}=0.62
$$

Year- and reef-specific demographic data were used to generate a description of reef-specific oyster biomass (in g dry tissue) for 1998 to 2009.

A 2-way analysis of variance (ANOVA; reef, year) was used to analyze total shell volume (in $\mathrm{L} / \mathrm{m}^{2}$ ) from 1998 through 2009. A second 2-way ANOVA (reef, year) was used to analyze brown shell volume data (in $\mathrm{L} / \mathrm{m}^{2}$ ) available from 2002 through 2009. Both total and brown shell volume data met the assumptions of homogeneity of variance and normality without transformation.

Density and biomass data satisfied assumptions of normality and homogeneity of variance after transformation (logarithm). An analysis of covariance (ANCOVA) with total shell volume $\left(\mathrm{L} / \mathrm{m}^{2} ; 1998\right.$ to 2009$)$ as a covariate, with reef and year as factors was used to evaluate density and biomass data (1 ANCOVA each for density and biomass).

Density and biomass data from sites with brown shell volume greater than 0 were also analyzed with separate ANCOVAs with brown shell volume (L/m², 2002 to 2009) as a covariate, and location and year as factors. Density and biomass data were log-transformed prior to analyses to satisfy the assumptions of normality and homogeneity of variance. Significance levels for all tests were established at alpha $=0.05$ a priori. Fisher's parametric post hoc multiple comparison test

\begin{tabular}{|c|c|c|c|c|c|c|c|c|c|c|c|c|}
\hline Reef & 1998 & 1999 & 2000 & 2001 & 2002 & 2003 & 2004 & 2005 & 2006 & 2007 & 2008 & 2009 \\
\hline (1) Ginney Point & 0 & 0 & 24.5 & 8.9 & 0 & 19.4 & 0 & 0 & 0 & 0 & 0 & 0 \\
\hline (2) Palace Bar & 0 & 0 & 4.5 & 1.6 & 0 & 3.6 & 0 & 0 & 0 & 0 & 1.8 & 0.2 \\
\hline (3) Bland Point & 0 & 0 & 5.9 & 2.2 & 0 & 4.7 & 0 & 0 & 0 & 0 & 2.6 & 0.3 \\
\hline (4) Heron Rock & 0 & 0 & 5.9 & 2.2 & 0 & 4.7 & 0 & 0 & 0 & 0 & 3.0 & 0.4 \\
\hline (5) Cape Toon & 0 & 0 & 8.9 & 3.2 & 0 & 7.0 & 0 & 0 & 0 & 0 & 2.2 & 0.3 \\
\hline (6) Stove Point & 0 & 0 & 7.0 & 2.6 & 0 & 5.6 & 0 & 0 & 0 & 0 & 0 & 0 \\
\hline (7) Burton Point & 0 & 0 & 2.8 & 1.0 & 0 & 2.2 & 0 & 0 & 0 & 0 & 0 & 0 \\
\hline (8) Burton Point 2 & 0 & 0 & 0 & 0 & 0 & 0 & 0 & 0 & 0 & 0 & 0 & 0 \\
\hline Seed removal as $\%$ of standing stock & & & 34.3 & 32.7 & & 26.8 & & & & & 21.6 & 2.4 \\
\hline
\end{tabular}
was used.

TABLE 9.

Seed removal $\left(\mathrm{L} / \mathrm{m}^{2}\right)$ from the public reefs in the Piankatank River between 1998 and 2009.

Reef areas are given in Table 2. The percentage of the total standing stock by number (Table 7) removed as seed is given at the bottom for all reefs combined within a year. 
TABLE 10.

Shell additions or plantings $\left(\mathrm{L} / \mathrm{m}^{2}\right)$ from 1998 to 2009 for the 8 public reefs examined in the Piankatank River.

\begin{tabular}{lcccccccccccc}
\hline \hline \multicolumn{1}{c}{ Reef } & $\mathbf{1 9 9 8}$ & $\mathbf{1 9 9 9}$ & $\mathbf{2 0 0 0}$ & $\mathbf{2 0 0 1}$ & $\mathbf{2 0 0 2}$ & $\mathbf{2 0 0 3}$ & $\mathbf{2 0 0 4}$ & $\mathbf{2 0 0 5}$ & $\mathbf{2 0 0 6}$ & $\mathbf{2 0 0 7}$ & $\mathbf{2 0 0 8}$ & $\mathbf{2 0 0 9}$ \\
\hline (1) Ginney Point & 9.2 & 9.8 & 0 & 34.4 & 0 & 24.3 & 12.2 & 6.1 & 0 & 0 & 0 \\
(2) Palace Bar & 13.9 & 7.9 & 16.2 & 5.8 & 0 & 11.6 & 8.8 & 8.9 & 0 & 0 & 5.9 & 0 \\
(3) Bland Point & 8.3 & 4.7 & 4.9 & 8.3 & 0 & 14.6 & 13.0 & 0 & 0 & 0 & 7.3 & 12.2 \\
(4) Heron Rock & 16.4 & 0 & 5.3 & 16.6 & 0 & 0 & 0 & 5.9 & 0 & 0 & 13.2 & 12.7 \\
(5) Cape Toon & 4.9 & 2.9 & 1.5 & 0 & 0 & 0 & 0 & 0 & 0 & 0 & 5.3 & 12.0 \\
(6) Stove Point & 13.4 & 0 & 0 & 0 & 0 & 20.3 & 0 & 7.0 & 0 & 0 & 0 & 11.6 \\
(7) Burton Point & 0 & 3.1 & 3.1 & 0 & 0 & 0 & 0 & 5.6 & 6.5 & 0 & 0 & 11.5 \\
(8) Burton Point 2 & 0 & 0 & 0 & 0 & 0 & 0 & 0 & 0 & 0 & 0 & 0 & 0 \\
\hline
\end{tabular}

Reef areas are given in Table 2.

\section{RESULTS}

\section{Temperature and Salinity}

There is good agreement between the water temperature predictions (Table 1), summer measurements, and sonde data series for the Piankatank River from 1998 through 2009 (Fig. 2). Summer maxima in the Piankatank River reached or exceeded $30^{\circ} \mathrm{C}$ in 2002, 2005, and 2006 (Fig. 2). Piankatank River winter minima were lowest (Fig. 2) in the winters of 1999 to 2000 and 2002 to $2003\left(\sim 0^{\circ} \mathrm{C}\right), 2004$ to $2005\left(1^{\circ} \mathrm{C}\right)$, and 2008 to 2009 $\left(\sim 2.5^{\circ} \mathrm{C}\right)$. During the winters of 1998 to 1999,2001 to 2002 , 2005 to 2006, and 2007 to 2008 Piankatank winter water temperatures remained at or above $5^{\circ} \mathrm{C}$ (Fig. 2).

Measured summer salinities during 1999, 2001, 2002, and 2003 were higher than the predicted values (Table 1, Fig. 3) with maximum measured salinities of 20-23 during summer 2002. Summer salinities in the Piankatank River were usually 14-18, with observed winter values of 9-11. Salinity minima occurred during the regional wet season from March through May, with maxima and a generally increasing trend observed in the regional dry season from June through November. Salinities were relatively high $(\sim 13)$ during the winter of 2005 to 2006 (Fig. 3).

\section{Description of the Oyster and Shell Resource}

\section{Oyster Density and Biomass}

The area of the individual reefs (sampling strata) varied by a factor of $6\left(2.12 \times 10^{4}-1.66 \times 10^{5} \mathrm{~m}^{2}\right.$, Table 2$)$. The Piankatank public reefs can generally be described as 2 groups on the basis of live oyster density (Table 2) and biomass (Table 3; g dry tissue $/ \mathrm{m}^{2}$ ). The reefs between Glebe Neck and Stove Point Neck (Fig. 1; Ginney Point, Palace Bar, Bland Point, and Stove Point, hereafter referred to as "northern") usually had the 4 highest values for density and biomass within a year, and these values were significantly higher than densities and biomass from Cape Toon, Heron Rock, Burton Point, and Burton Point 2, hereafter referred to as "southern" (ANCOVAs, Table 4, Fig. 1).

The $2 \mathrm{y}$ of highest recruitment, density, and biomass during the study period were 1999 and 2002 (Table 4). In 2002, the 4 northern reefs had densities 3-4 times higher than densities on the southern reefs (188.9-269.9 vs. 36.4-50.0 oysters $/ \mathrm{m}^{2}$; Table $2)$. The lowest densities $\left(<12\right.$ oysters $\left./ \mathrm{m}^{2}\right)$ and biomass $\left(<3 \mathrm{~g} / \mathrm{m}^{2}\right)$ were observed throughout the system in 2005 (Tables 2, 3, and
4 ), with gradually increasing densities and biomass observed in 2007 and 2008

Both oyster density and biomass were significantly affected by year, reef, and total shell volume (Table 4, Table 5), as well as brown shell volume (Table 4, Table 6). Palace Bar and Bland Point had significantly higher total shell volume than Stove Point, Heron Rock, and Cape Toon (Table 4) with all reefs having higher total shell volume than Burton Point 2.

The shell material collected in the surveys and quantified in units of $\mathrm{L} / \mathrm{m}^{2}$ for each sample ranged in size from intact oyster shells to shell fragments. Total shell volume (brown and black shell) was recorded in all years (Table 5). Brown shell was quantified separately from 2002 through 2009 (Table 6). Brown shell results from mortality and repletion activity. The time frame for decay or disappearance of brown shell may be on the order of years (Powell et al. 2006). Once buried, brown shell becomes black shell. Black shell is unavailable as oyster habitat and has a different decay rate (half life) than brown shell. Total shell volume data collected in November surveys reflect additions

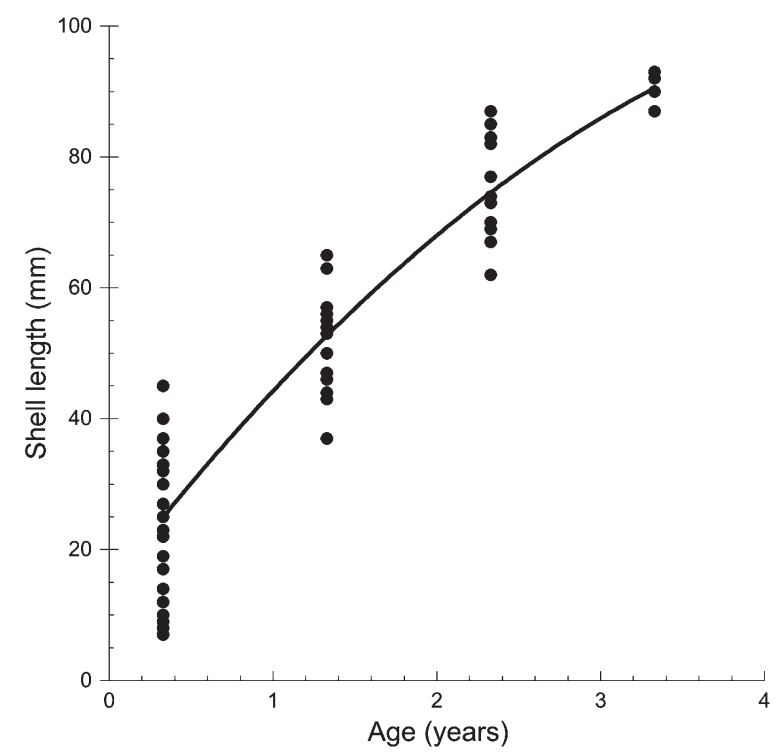

Figure 5. Estimation of Piankatank River oyster age-at-length based on data from all public reefs from 2003 through 2009. The quadratic model is $\mathrm{SL}=-2.947 \times(\mathrm{Age})^{2}+32.6565 \times($ Age $)+14.4516 ; R^{2}=0.87$. 
TABLE 11.

Regression coefficients for Piankatank River oyster age-at-length relationships.

\begin{tabular}{lrcccrrrr}
\hline \hline Year & $\boldsymbol{n}$ & $\mathbf{a}$ & SE a & b & \multicolumn{1}{c}{ SE $\mathbf{b}$} & \multicolumn{1}{c}{$\mathbf{c}$} & \multicolumn{1}{c}{ SE $\mathbf{c}$} & $\boldsymbol{R}^{\mathbf{2}}$ \\
\hline All & 72 & -2.9470 & 1.2124 & 32.6565 & 3.9368 & 14.4516 & 2.5131 & 0.87 \\
2003 & 11 & -1.1364 & 1.9141 & 21.5379 & 6.7607 & 30.1375 & 4.4667 & 0.94 \\
2004 & 8 & -2.2500 & 4.0289 & 23.4017 & 10.6982 & 23.1891 & 5.5325 & 0.91 \\
2005 & 8 & -7.7083 & 9.3126 & 42.8792 & 22.8395 & 8.9393 & 10.6549 & 0.78 \\
2006 & 12 & -3.1745 & 2.6166 & 33.5999 & 8.7343 & 16.7672 & 5.5667 & 0.91 \\
2007 & 10 & -4.9167 & 7.2805 & 39.9950 & 19.4657 & 7.8371 & 9.4852 & 0.87 \\
2008 & 11 & -4.1667 & 2.8651 & 39.2500 & 9.5463 & 7.5013 & 6.2803 & 0.93 \\
2009 & 12 & -5.3093 & 2.7937 & 44.4096 & 9.3593 & 2.3365 & 6.3866 & 0.93 \\
\hline
\end{tabular}

Cohort analyses (Bhattacharya 1967) were conducted on individual oyster measurements ( $n=13,349$ oysters) made from 2003 through 2009. $n=$ the number of (age, shell length) data pairs from cohort analysis that contribute to each equation. $\mathrm{SE}=$ standard error for regression coefficient. Parameters and error terms are given for the quadratic model where $\mathrm{SL}=\mathrm{a} \times(\text { Age })^{2}+\mathrm{b} \times($ Age $)+\mathrm{c}$.

from recruitment, mortality, and repletion-related shell additions (plantings) in the preceding spring (discussed later).

All reefs had significantly higher total shell volume than Burton Point $2\left(<10 \mathrm{~L} / \mathrm{m}^{2}\right)$. Observed total shell volumes ranged from $2.0 \mathrm{~L} / \mathrm{m}^{2}$ (Burton Point 2, 2004) to $22.0 \mathrm{~L} / \mathrm{m}^{2}$ (Bland Point, 2002; Table 5). Total shell volume was highest in 2002 (Table 4), corresponding to both high recruitment in 2002 and the mortality of the 1999-y class between 1999 and 2002 (Table 5). Brown shell volumes ranged from $0.6-0.7-15.7 \mathrm{~L} / \mathrm{m}^{2}$, with Ginney Point having significantly higher brown shell volume than the reefs on the southern side of the channel (Fig. 1, Table 4). All the northern reefs between Glebe Neck and Stove Point Neck had significantly higher brown shell volume than Cape Toon and Burton Point 2 (Tables 4 and 6), similar to the observed density trends.

Spatial trends in oyster distribution within reefs can be examined through variance-to-mean ratios from replicate samples collected on the same reef within a year (Fig. 4, ratios $>1$ indicate aggregation, ratios $=1$ describe a random distribution, values $<1$ indicate a uniform distribution). Variance to mean ratios for live oyster density data from the Piankatank public reefs range from 0.9-155.3 (Fig. 4A). Almost all $(99 \%)$ the observed variance-to-mean ratios for density data from the Piankatank River are greater than 1 (Fig. 4A), indicating aggregated distributions of oysters, which is expected for reef-building oysters with gregarious settlement behavior. Most $(70 \%)$ of these ratios are between 10 and 80 , with no values between 80 and 100 . These values are generally similar to variance-to-mean ratio values for oyster densities of 10-100 observed in other natural populations of Chesapeake Bay oysters (Mann et al. 2009b, Southworth et al. 2010b).

All variance-to-mean ratios for total shell volume (in $\mathrm{L} / \mathrm{m}^{2}$ ) were all less than 20 , with $94 \%$ of values less than 10 (Fig. 4B) and a median of 3.9. The variance-to-mean ratios for brown shell volume (in $\mathrm{L} / \mathrm{m}^{2}$; Fig. 4C) ranged from $0.5-22.9$, with $92 \%$ of observed values equal to 10 or less and a median of 4.2 . The observed variance-to-mean ratios for total and brown shell volume are also characteristic of aggregated distributions as expected in biogenic reef habitats occupying historic reef footprints (Baylor 1896) formed on geologic timescales.

TABLE 12.

Age demographics (number of oysters within an age class per square meter) for the public reefs in the Piankatank River from 1998 through 2009.

\begin{tabular}{cccccccccccccc}
\hline \hline Reef Group & Age Class & $\mathbf{1 9 9 8}$ & $\mathbf{1 9 9 9}$ & $\mathbf{2 0 0 0}$ & $\mathbf{2 0 0 1}$ & $\mathbf{2 0 0 2}$ & $\mathbf{2 0 0 3}$ & $\mathbf{2 0 0 4}$ & $\mathbf{2 0 0 5}$ & $\mathbf{2 0 0 6}$ & $\mathbf{2 0 0 7}$ & $\mathbf{2 0 0 8}$ & $\mathbf{2 0 0 9}$ \\
\hline \multirow{2}{*}{ Northern } & YOY & $\mathbf{6 1 . 5}$ & 219.5 & $*$ & $*$ & $\mathbf{2 0 6 . 2}$ & $*$ & 1.6 & 2.1 & $\mathbf{4 0 . 8}$ & 44.7 & $*$ & $*$ \\
& 1 & 14.8 & $\mathbf{1 4 . 9}$ & $*$ & $*$ & 14.4 & $*$ & 5.5 & 1.8 & 12.2 & $\mathbf{2 8 . 7}$ & $*$ & $*$ \\
& 2 & 6.6 & 1.7 & $*$ & $*$ & 3.36 & $*$ & 1.0 & 1.2 & 1.8 & 4.6 & $*$ & $*$ \\
& 3 & 0.5 & 0.3 & $*$ & $*$ & 0.3 & $*$ & 0.1 & 0.1 & 0.7 & 0.5 & $*$ & $*$ \\
& 4 & 0 & 0 & $*$ & $*$ & 0 & $*$ & 0 & 0 & 0.1 & 0 & $*$ & $*$ \\
& Total & 83.4 & 236.4 & $*$ & $*$ & 224.3 & $*$ & 5.3 & 5.3 & 55.5 & 78.5 & $*$ & $*$ \\
\multirow{5}{*}{ Southern } & YOY & $\mathbf{1 2 . 7}$ & 28.9 & $*$ & $*$ & $\mathbf{3 9 . 9}$ & $*$ & 0.2 & 0.6 & $\mathbf{1 3 . 9}$ & 13.6 & $*$ & $*$ \\
& 1 & 3.5 & $\mathbf{2 . 7}$ & $*$ & $*$ & 2.9 & $*$ & 1.2 & 0 & 2.4 & $\mathbf{1 0 . 4}$ & $*$ & $*$ \\
& 2 & 1.4 & 0.4 & $*$ & $*$ & 1.3 & $*$ & 0.6 & 0.2 & 0.5 & 1.1 & $*$ & $*$ \\
& 3 & 0.1 & 0 & $*$ & $*$ & 0.1 & $*$ & 0 & 0.1 & 0.2 & 0 & $*$ & $*$ \\
& 4 & 0 & 0 & $*$ & $*$ & 0 & $*$ & 0 & 0 & 0.1 & 0 & $*$ & $*$ \\
\multirow{5}{*}{ All reefs } & Total & 17.7 & 32.1 & $*$ & $*$ & 44.2 & $*$ & 2.1 & 0.8 & 17.0 & 25.1 & $*$ & $*$ \\
& YOY & $\mathbf{3 3 . 9}$ & 11.7 & $*$ & $*$ & $\mathbf{1 1 2 . 1}$ & $*$ & 0.8 & 1.2 & $\mathbf{2 7 . 0}$ & 26.4 & $*$ & $*$ \\
& 1 & 8.4 & $\mathbf{8 . 0}$ & $*$ & $*$ & 7.9 & $*$ & 3.1 & 0.8 & 5.5 & $\mathbf{1 9 . 0}$ & $*$ & $*$ \\
& 2 & 3.7 & 1.0 & $*$ & $*$ & 2.2 & $*$ & 0.7 & 0.6 & 0.9 & 2.5 & $*$ & $*$ \\
& 3 & 0.2 & 0.1 & $*$ & $*$ & 0.2 & $*$ & 0 & 0.1 & 0 & 0.2 & $*$ & $*$ \\
& 4 & 0 & 0 & $*$ & $*$ & 0 & $*$ & 0 & 0 & 0 & 0 & $*$ & $*$ \\
& Total & 46.2 & 120.8 & $*$ & $*$ & 122.4 & $*$ & 4.7 & 2.8 & 33.5 & 48.2 & $*$ & $*$ \\
\hline
\end{tabular}

Northern reefs (Ginney Point, Palace Bar, Stove Point, Bland Point) are distinct from southern reefs (Burton Point, Burton Point 2, Heron Rock, Cape Toon) statistically and hydrographically as discussed in the text. Age demographics are recast from length demographics as described in the text. Cohorts progress diagonally with time. YOY = young of the year. Bold text highlights the diagonal progression of the 1998-, 2002-, and 2006-y classes as described in the text.

* Denotes years in which seed removal in the spring compromises estimation of the population demographics recorded in the fall survey. 
TABLE 13.

Location-specific proportional mortality rates for the public reefs in the Piankatank River from 1999 through 2009.

\begin{tabular}{|c|c|c|c|c|c|c|c|c|c|c|c|c|c|}
\hline Reef Group & Transition & 1999 & 2000 & 2001 & 2002 & 2003 & 2004 & 2005 & 2006 & 2007 & 2008 & 2009 & Mean \\
\hline \multirow{3}{*}{ Northern } & YOY-1 & 0.76 & $*$ & $*$ & 0.32 & $*$ & $\dagger$ & $\dagger$ & $\dagger$ & 0.30 & 0.58 & 0.67 & 0.52 \\
\hline & $1-2$ & 0.88 & $*$ & $*$ & 0.78 & $*$ & $\dagger$ & $\dagger$ & $\dagger$ & 0.62 & 0.55 & 0.68 & 0.70 \\
\hline & $2-3$ & 0.96 & $*$ & $*$ & 0.88 & $*$ & $\dagger$ & $\dagger$ & $\dagger$ & 0.73 & 0.66 & 0.91 & 0.83 \\
\hline \multirow[t]{3}{*}{ Southern } & YOY-1 & 0.79 & $*$ & $*$ & 0.60 & $*$ & $\dagger$ & $\dagger$ & $\dagger$ & 0.26 & $*$ & $*$ & 0.55 \\
\hline & $1-2$ & 0.89 & $*$ & $*$ & 0.74 & $*$ & $\dagger$ & $\dagger$ & $\dagger$ & 0.57 & $*$ & $*$ & 0.73 \\
\hline & $2-3$ & 0.99 & * & * & 0.95 & * & $\dagger$ & $\dagger$ & $\dagger$ & 0.90 & $*$ & $*$ & 0.95 \\
\hline \multirow[t]{3}{*}{ All reefs } & YOY-1 & 0.76 & * & * & 0.41 & * & $\dagger$ & $\dagger$ & $\dagger$ & 0.30 & 0.58 & 0.67 & 0.54 \\
\hline & $1-2$ & 0.89 & $*$ & $*$ & 0.77 & $*$ & $\dagger$ & $\dagger$ & $\dagger$ & 0.54 & 0.55 & 0.68 & 0.68 \\
\hline & $2-3$ & 0.96 & $*$ & $*$ & 0.91 & $*$ & $\dagger$ & $\dagger$ & $\dagger$ & 0.74 & 0.66 & 0.91 & 0.84 \\
\hline
\end{tabular}

Northern reefs (Ginney Point, Palace Bar, Stove Point, Bland Point) are distinct from southern reefs (Burton Point, Burton Point 2, Heron Rock, Cape Toon) statistically and hydrographically as discussed in text. YOY = young of the year. During 2008 and 2009, mortality rates for northern reefs are based on Ginney Point data because there were no seed removals or shell plants to this reef during these years.

* Denotes years in which seed removal in the spring compromises estimation of the population mortality rates.

$\uparrow$ Denotes years in which extremely low densities prevent accurate estimation of shell budgets.

\section{Oyster Standing Stocks}

Standing stock in numbers (Table 7) and biomass (Table 8) from 1998 through 2009 was estimated by multiplying the average oyster density and biomass per unit area (Tables 2 and 3) by the reef area. Total numbers of oysters in the surveyed area varied between a low value of $2.12 \times 10^{4}$ in 2004 and a high value of $5.46 \times 10^{7}$ in 1999 . The 1999 recruitment increased the standing stock $\sim 2.5$ times from 1998 , with an increase from $3.33 \times$ $10^{7}-8.70 \times 10^{7}$. The 2002 recruitment increased the standing stock $\sim 4$-fold above 2001 , with an increase from $1.79 \times 10^{7}-8.82 \times$ $10^{7}$. The 2006 recruitment was notable in that it increased standing stock $\sim 12$-fold more than 2005 levels. Modest recruitment was also observed in 2007 and 2008.

The 2002 recruitment event resulted in a biomass increase to $8.75 \times 10^{6} \mathrm{~g}$ (Table 8), followed by a gradual decrease in 2003 to 2005 , to the lowest value throughout the study of $8.36 \times 10^{5} \mathrm{~g}$ observed in 2005. The low standing stock observed in 2005 is the product of mortality combined with seed removal in spring 2003 (which has a cascading effect on demographics and shell dynamics for several years past the event, as described later). The years 2006 through 2009 were accompanied by a 2-fold increase in biomass to a 2009 value of $1.15 \times 10^{7} \mathrm{~g}$.

The spatial variation in absolute density reflects cumulative patterns of recruitment and postrecruit survival. Biomass-perunit-area values are less influenced by sporadic recruitment events because the losses in numbers after recruitment are offset by the increasing biomass per individual. An increase in biomass is expected in the 1-2 y after a year of good recruitment. However, seed removal in the early spring (Table 9; 2000, 2001, 2003) after a year of strong recruitment $(1999,2002)$ will remove or dampen this trend. Oyster seed at 500 /bu were removed from the Piankatank public reefs in 2000, 2001, 2003, 2008, and 2009, representing approximately $34 \%, 32 \%, 27 \%, 22 \%$, and $2 \%$ of the total standing stock by number, respectively (Table 9 ).

\section{The Shell Resource}

In addition to shell from natural recruitment, growth, and mortality, selected reefs received supplemental shell planting at different times during the study period (Table 10). To optimize availability for recruitment, shell was planted after seed removal (early spring) but before the end of July. The shell planting additions are reflected in the observed total shell (Table 5) and brown shell (Table 6) volumes recorded on November surveys, although additions must be balanced against shell removal as part of seed harvesting. These reef-specific manipulations in support of repletion mask the natural burial and shell degradation processes.

The relationship of repletion activity (seed removal, shell planting) with the survey values of total and brown shell volume illustrates the impoverished state of the underlying reef substrate on these public reefs. For example, seed was removed from Ginney Point in early spring 2003 (19.4 L/m², Table 9). Shell was planted at Ginney Point in late spring/early summer $2003\left(24.3 \mathrm{~L} / \mathrm{m}^{2}\right.$, Table 10$)$, with average total and brown shell volumes of $12.4 \mathrm{~L} / \mathrm{m}^{2}$ and $9.3 \mathrm{~L} / \mathrm{m}^{2}$, respectively, recorded in November 2003 (Tables 5 and 6).

\section{Estimation of Oyster Age at Length}

The quadratic relationship SL $=\mathrm{a} \times(\text { Age })^{2}+\mathrm{b} \times($ Age $)+\mathrm{c}$ was used to estimate age-at-length for Piankatank River oysters (Fig. 5, Table 11). Examination of year-specific model coefficients

TABLE 14.

\section{Recruit-to-stock (R/S) ratios for all 8 of the Piankatank River public reefs from1999 through 2009.}

\begin{tabular}{lc}
\hline \hline Year & R/S Ratio \\
\hline 1999 & 5.96 \\
2000 & $3.69^{*}$ \\
2001 & $1.48^{*}$ \\
2002 & 7.15 \\
2003 & $1.84^{*}$ \\
2004 & 0.18 \\
2005 & 0.32 \\
2006 & 17.76 \\
2007 & 3.22 \\
2008 & $1.79^{*}$ \\
2009 & $0.71 *$ \\
Average & 4.01 \\
\hline
\end{tabular}

Ratios in years of seed removal in the spring prior to the fall surveys have been corrected for seed removal (*) as discussed in text. 
revealed very modest changes from year to year (Table 11), and the model for all years was used to recast length demographics as age demographics and to estimate age-specific mortality. Using a July 1 birth date and noting that current data are for a fall survey, then lengths on November 1 represent ages of $0.33 \mathrm{y}, 1.33 \mathrm{y}$, and so on with annual increments. For clarity throughout the rest of the text, these ages will be referred to as $0-, 1-, 2-$, and 3-y-olds, respectively. Corresponding SL are $24.9 \mathrm{~mm}$ at $0 \mathrm{y}, 52.6 \mathrm{~mm}$ at $1 \mathrm{y}, 74.5 \mathrm{~mm}$ at $2 \mathrm{y}$, and $90.5 \mathrm{~mm}$ at $3 \mathrm{y}$.

The current estimates of age-at-length are commensurate with the $0-3$-y classes for the linear age-at-length relationships reported by Harding et al. (2008) and Mann et al. (2009b) in the James River, Virginia, and the quadratic age-at-length relationships reported by Southworth et al. (2010b) in the Great Wicomico River, Virginia. The curvature of the quadratic fit dictates smaller length at age for older individuals than a linear fit.

\section{Age Structure, Mortality, Shell Budget, and Recruit-to-Stock Ratio}

Age structure was described for northern, southern, and all reefs using the quadratic age-at-length relationship to discriminate year classes from the measured population demographics in each year. In general, the progression of a cohort over time may be followed by moving diagonally and down each year (Table 12).
Recruitment and young of the year (YOY) densities are consistently higher at the northern reefs than at the southern reefs (Table 12) by a factor of 3-6. Both groups of reefs display synchronous recruitment patterns over time. The highest recruitments were observed in 1999 and 2002, with steady but modest recruitment observed in 1998, 2000, and 2006 through 2009 (Table 12). Age 1+y classes represent approximately $30 \%$ and $34 \%$ of the total population on northern and southern reefs, respectively. The skewed nature of the population demographic toward YOY throughout the river system speaks to the influence of predation and disease on age structure.

A description of the mortality for the northern and southern reef groups is complicated by seed removal in the spring preceding the annual fall surveys (2000, 2001, 2003, 2008, and 2009; Table 9), very low standing stock (2004, 2005; Table 7), and the presence of essentially only YOY (2006). Mortality was estimated as described in Eq. 1 for northern, southern, and all reefs combined during 1999, 2002, 2007, years in which the cohort signal remains uncompromised (Table 13). Mortality estimates for 2008 and 2009 are based on Ginney Point alone because all other northern reefs had seed removed in these years and all southern reefs had either very low densities or seed removal.
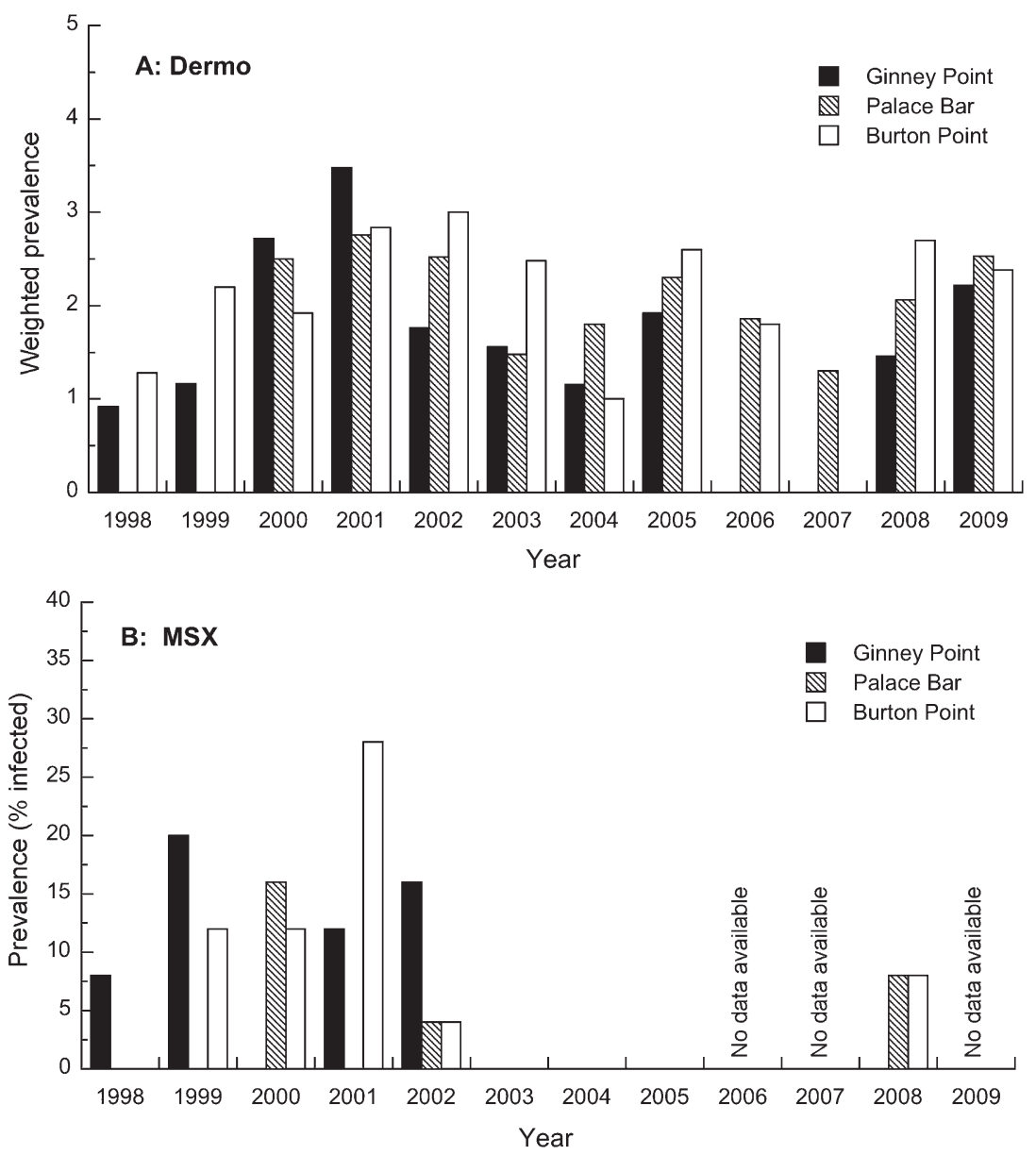

Figure 6. (A, B) Weighted prevalence of Perkinsus marinus (A; 1998 to 2009) and prevalence of Haplosporidium nelsoni (B; 1998 to 2005,2008$)$ at reefs 1,2 , and 7 . Weighted prevalence is on a scale of 0 (no disease detected) to $5(100 \%$ with heavy infections). Prevalence uses a scale from $0 \%$ (no oysters infected) to $100 \%$ (all oysters sampled infected). Data are from Ragone Calvo and Burreson (1999, 2000, 2001, 2002, 2003), Carnegie et al. (2004) and Carnegie and Burreson $(2005,2006,2009)$, and are used with permission. 
Mean annual mortality rates for YOY, Age 1-, and Age 2-y classes are comparable for northern and southern reefs (Table 13) with values of $0.52,0.7$, and 0.83 for northern, and 0.55 , 0.73 , and 0.95 for southern reefs, respectively. These rates correspond to cumulative mortality values of 0.52 (YOY), 0.86 (Age 1), and 0.95 (Age 2) for the northern reefs, with values of $0.55,0.88$, and 0.99 observed on the southern reefs. Age $3+$ individuals are very rare (Table 12 ) throughout the system.

The separation of the YOY from $\geq 1$-y-old oysters is based on the age-at-length relationship (Fig. 5, Table 11). The recruitto-stock $(\mathrm{R} / \mathrm{S})$ ratio is generated from the stock $(\mathrm{S}$, year $\mathrm{t})$ and recruit $(R$, year $t+1)$ data. This ratio describes the riverwide stock at basin wide spatial scales with an assumption of no immigration, and a scenario in which all larvae have the opportunity to recruit within the basin. The 2000, 2001, 2003, 2008, and 2009 signals were compromised by seed removal (Table 9). The total population demographic estimate (Table 12) was corrected annually for any seed removal (Table 9), with the assumption that seed removal takes all year classes in proportion to their abundance (no bias in removal of $1 \mathrm{y}$ class over the others). Using the resulting YOY in 1 y $\left(t_{1}\right)$ with the animals older than YOY in the preceding year $\left(\mathrm{t}_{0}\right)$ for 1998 through 2009, we estimated R/S ratios during 1999 through 2009 (Table 14). R/S values greater than 1.0 would typically suggest an expanding population. In a seed river, $\mathrm{R} / \mathrm{S}$ values in excess of 1 are required to maintain seed production and populate shell plants. Only 3 of the 11 Piankatank River R/S values from 1999 through 2009 are less than 1, with the highest observed value of 17 (2006, Table 14).

Haven et al. (1978, p 262) point out: "Survival in a successful seed area is good because of the absence of significant levels of mortality or endemic diseases. This allows accumulation of oysters over the years in the area, assuming that harvesting is not excessive, other environmental conditions are good, and predation is not excessive." The observed $\mathrm{R} / \mathrm{S}$ values are consistent with Haven et al. (1978) and support the suggestion that this would be the case in the Piankatank River in the absence of extensive seed harvest and disease activity.

Considering all data for the 1998 to 2009 period, we cannot identify a predictive $\mathrm{R} / \mathrm{S}$ relationship for the oysters on public reefs within the Piankatank wherein stock in year $t_{0}$ can be used to predict the number of recruits the following year. The history of seed harvest during the study confounds attempts to derive a stock-recruit relationship for the entire study period. Examination of the years in which seed are not removed during the study period does identify a long-term $\mathrm{R} / \mathrm{S}$ ratio of 5.4 independent of seed removal. The range of observed $\mathrm{R} / \mathrm{S}$ ratios (3.2-7.2, with an exception of 17.2 in 2006; Table 14) are modest in years during which there is no seed removal and when densities are greater than 10 oysters $/ \mathrm{m}^{2}$ throughout the system (Table 2).

\section{Disease Impacts on Mortality}

Both Dermo (P. marinus) and MSX (H. nelsoni) have been present in the Piankatank River since the early 1960s (Haven et al. 1978, Andrews 1988, Andrews 1996, Burreson \& Ragone Calvo 1996). Epizootics of both diseases were also observed during the current study (Fig. 6) (Ragone Calvo \& Burreson [1999, 2000, 2001, 2002, 2003], Carnegie et al. 2004, Carnegie \& Burreson [2005, 2006, 2009]). The prevalence and intensity of both diseases are related to salinity and temperature (Ford \& Haskin 1982, Andrews 1988). Expulsion of Dermo requires exposure to salinities less than 3 ppt (Burreson \& Ragone Calvo 1996) whereas MSX can be expulsed at salinities less than $10 \mathrm{ppt}$ (Andrews 1988, Burreson \& Ragone Calvo 1996). Once established in a coastal plain estuary like the Piankatank River, Dermo can persist at low levels indefinitely (Andrews 1996).

The observed Dermo WP values from 2000 through 2002 are consistently more than 2 (Fig. 6), with the highest value (3.5) observed in 2001 commensurate with year-round warm temperatures (Fig. 2) and relatively high salinities (Fig. 3). From 1999 through 2001, the oyster standing stock declined (Table 7), but increased in 2002 even with disease mortality and seed

TABLE 15.

Accretion rates for the northern and southern groups of Piankatank River public reefs as well as the total for all public reefs surveyed.

\begin{tabular}{|c|c|c|c|c|c|c|c|c|c|c|c|c|}
\hline Location & $\begin{array}{l}\text { Accretion Rate } \\
\left(\mathrm{L} / \mathrm{m}^{2} / \mathrm{y}\right)\end{array}$ & 1999 & 2000 & 2001 & 2002 & 2003 & 2004 & 2005 & 2006 & 2007 & 2008 & 2009 \\
\hline \multirow[t]{3}{*}{ Northern } & Min & 1.60 & $*$ & $*$ & 0.81 & $*$ & $\dagger$ & $\dagger$ & $\dagger$ & 0.66 & 1.77 & 2.31 \\
\hline & Mean & 3.17 & $*$ & $*$ & 1.44 & $*$ & 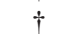 & $\dagger$ & $\dagger$ & 1.22 & 3.46 & 3.52 \\
\hline & Max & 4.75 & $*$ & $*$ & 2.06 & $*$ & $\dagger$ & $\dagger$ & $\dagger$ & 1.77 & 5.16 & 4.73 \\
\hline \multirow[t]{3}{*}{ Southern } & Min & 0.22 & $*$ & $*$ & 0.21 & * & $\dot{\dagger}$ & $\dagger$ & $\dot{\dagger}$ & 0.06 & 0.12 & 0.91 \\
\hline & Mean & 0.44 & $*$ & * & 0.40 & $*$ & $\dagger$ & $\dagger$ & $\dagger$ & 0.11 & 0.23 & 1.42 \\
\hline & $\operatorname{Max}$ & 0.66 & $*$ & $*$ & 0.58 & $*$ & $\dagger$ & $\dagger$ & $\dagger$ & 0.16 & 0.35 & 1.93 \\
\hline \multirow[t]{3}{*}{ All reefs } & Min & 0.82 & $*$ & $*$ & 0.47 & $*$ & $\dagger$ & $\dagger$ & $\dagger$ & 0.32 & 0.44 & 1.18 \\
\hline & Mean & 1.63 & $*$ & $*$ & 0.85 & $*$ & $\dagger$ & $\dagger$ & $\dagger$ & 0.59 & 0.86 & 1.82 \\
\hline & Max & 2.43 & $*$ & * & 1.22 & $*$ & $\dagger$ & $\dagger$ & $\dagger$ & 0.86 & 1.28 & 2.47 \\
\hline
\end{tabular}

Northern reefs (Ginney Point, Palace Bar, Stove Point, Bland Point) are distinct from southern reefs (Burton Point, Burton Point 2, Heron Rock, Cape Toon) statistically and hydrographically as discussed in text. The time course of shell accretion is time lagged by $1 \mathrm{y}$ with respect to the year class recruitment event. Estimates for minimum (Min), mean, and maximum (Max) shell accretion rates indicate the uncertainty related to the time of death between annual surveys and are uncorrected for subsidence. Accretion rates that exceed the required equilibrium value of $4.55 \mathrm{~L} / \mathrm{m}^{2} / \mathrm{y}$ for the Chesapeake region (explained in text (Mann et al. 2009a)) are in bold type.

* Years in which estimation of shell budgets from the fall survey is compromised by seed removal in the spring of the same year.

$\dagger$ Years in which extremely low densities prevent accurate estimation of shell budgets. 
removal. Andrews (1996, p 14) suggested that the Piankatank is "effective in producing seed oysters with quite regular spatfalls. The diseases have not affected setting rates in the coastal plain estuaries because low populations of broodstock are adequate." The current demographic, disease, and mortality data bear this suggestion out. Even with high disease levels from 1999 to 2002, the systemwide average $\mathrm{R} / \mathrm{S}$ ratio was 4.6 !

MSX was present in the Piankatank River from 1998 through 2002, and in 2008, but absent from 2003 through 2005 (Fig. 6B) and has been present in the system since 1963 (Andrews \& Wood 1967, Haven et al. 1978). No data were available for 2006, 2007, and 2009. The coincidence of both diseases on at least 2 if not all 3 reefs from 1999 through 2002 (Fig. 6) likely contributed to the observed demise of older oysters in the Piankatank during these years (Tables 12 and 13). A similar dynamic may currently be in progress, because both diseases were observed in 2008 (Fig. 6).

\section{Contribution of Mortality to the Shell Habitat Base}

Shell habitat is maintained by addition from mortality and is lost to burial and taphonomic processes. Persistence of habitat is dependent on the rates of each process (Powell et al. 2006, Powell \& Klinck 2007, Mann \& Powell 2007, Mann et al. 2009a, Mann et al. 2009b). A positive shell accretion balance of the order of $4.55 \mathrm{~L} / \mathrm{m}^{2} / \mathrm{y}$ (Mann et al. 2009a) is required over extended periods to compensate for sea level rise (Pyke et al. 2008) and natural shell degradation processes (Powell et al. 2006, Powell \& Klinck 2007) in the Chesapeake region. The relationship between oyster SL (in $\mathrm{mm}$ ) and oyster WSW (in g) for 651 Piankatank River oysters (SL range, 26-109 mm) collected between 2004 and 2009 was described using a power equation:

$$
\mathrm{WSW}(\mathrm{g})=0.00041132 \times \mathrm{SL}(\mathrm{mm})^{(2.7766)} ; R^{2}=0.76
$$

This relationship was used to estimate the amount of live WSW (in $\mathrm{g} / \mathrm{m}^{2}$ ) observed in each patent tong on the basis of live oyster demographics. The volumetric conversion from Mann et al. (2009b) was used to convert grams of shell to liters of shell herein.

Mann et al. (2009a) presented high and low rate estimates for mortality contribution to the habitat based on when, in the year between surveys, individuals died. A parallel analysis for public oyster reefs in the Piankatank River is presented in Table 15. Data are presented for northern reefs, southern reefs, and all reefs combined. Shell accretion rates are the product of both age-specific mortality and the size of the individual at death. Thus, the time course of shell accretion is time lagged by $1 \mathrm{y}$ with respect to the year class recruitment event. Calculation of a shell accretion rate is compromised in years in which seed are removed in the spring prior to the fall survey and when population densities are very low. Of the $5 \mathrm{y}$ for which accretion rates are available $(1999,2002,2007-2009$; Table 15) there are only $3 \mathrm{y}$ for the northern reefs alone that support accretion rates greater than $4 \mathrm{~L} / \mathrm{m}^{2} / \mathrm{y}$, using the maximum accretion rate estimates. The required shell accretion rate for equilibrium with sea level rise and natural degradation processes is $4.55 \mathrm{~L} / \mathrm{m}^{2} / \mathrm{y}$ (Mann et al. 2009a), and represents a sustainable reef habitat in the absence of repletion or disturbance by harvest (Mann et al. 2009b). The observed deficit in other years and other locations is indicative of the requirement for shell addition (planting) to maintain shell habitat base.

\section{Oyster Shell as Habitat on Public Reefs}

The relationship between the shell resource and oyster populations on public oyster reefs in the Piankatank River is described for all reef/year combinations (Fig. 7A) and by year
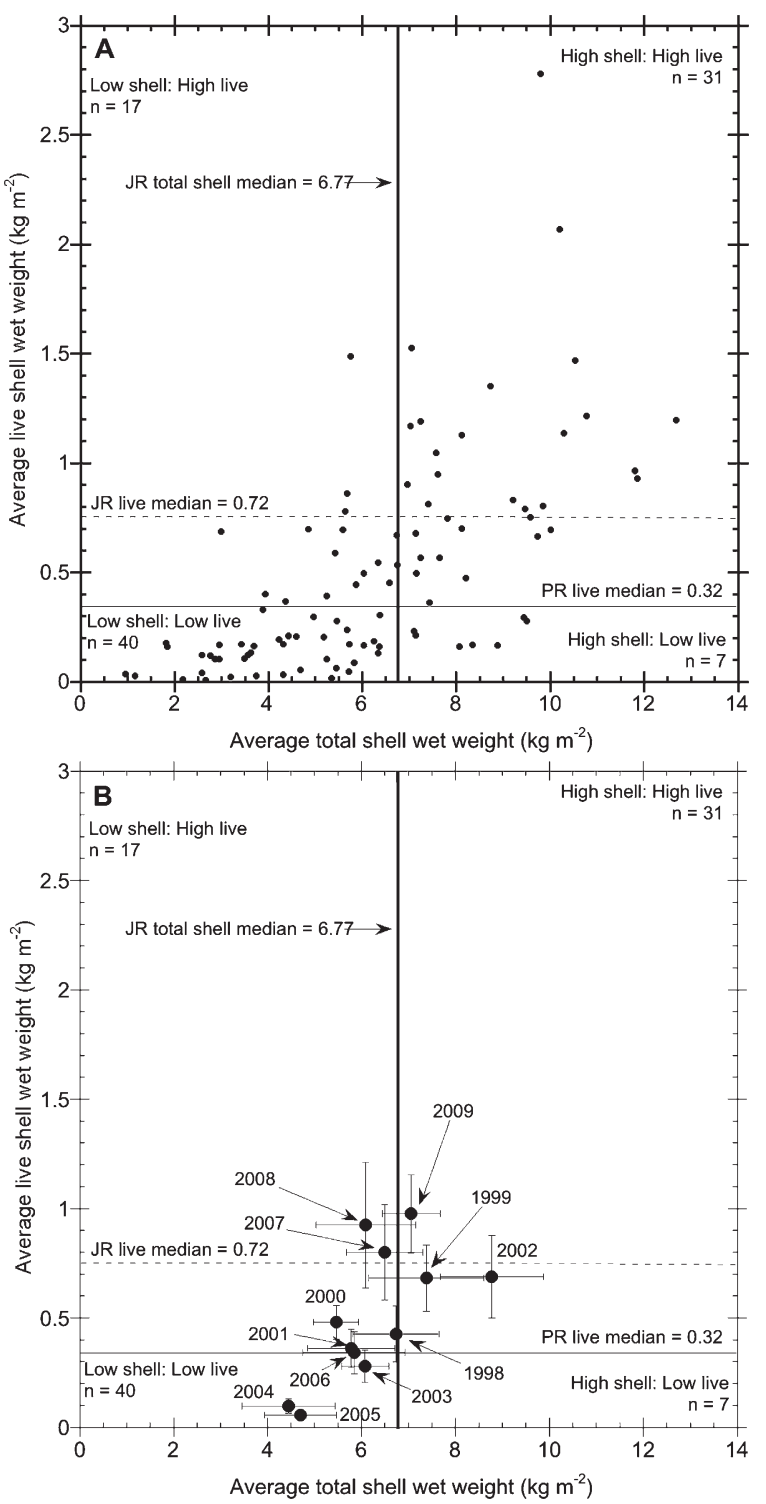

Figure 7. (A, B) The relationship of Piankatank River live oyster shell wet weight (kilograms per square meter) to total shell wet weight $\left(\mathrm{kg} / \mathrm{m}^{2}\right)$ on a per-unit-area basis for all reef/year combinations (A) and all reefs by year (B) for patent tong samples with total shell wet weight more than $0 \mathrm{~kg} / \mathrm{m}^{2}$. The number of data points in each quadrant are indicated (A). The derivation of the $\mathbf{4}$ quadrants (low shell, high live; high shell, high live; low shell, low live; and high shell, low live) are based on Mann et al. (2009b). The live shell wet weight median value for the Piankatank River (PR) public reefs $(\mathrm{A}, 0.32)$ is presented with corresponding median values for natural public oyster reefs in the James River (JR, 0.72 (Mann et al. 2009b)). The median values for live shell (0.72) and total shell (6.77) from the James River public reefs (Mann et al. 2009b) are used to place the year-specific (B) values from the Piankatank River public reefs in context. 

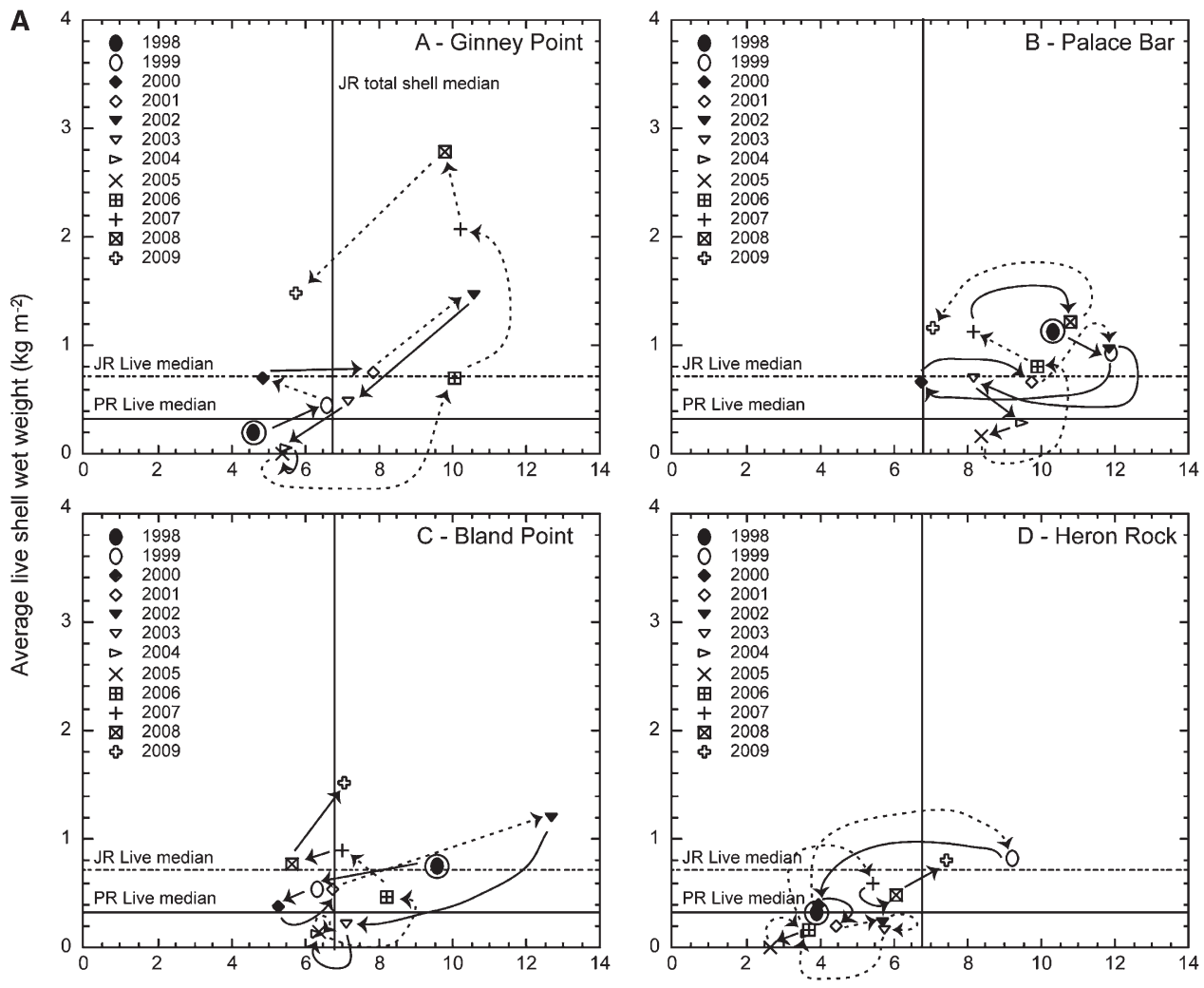

Average total shell wet weight $\left(\mathrm{kg} \mathrm{m}^{-2}\right)$

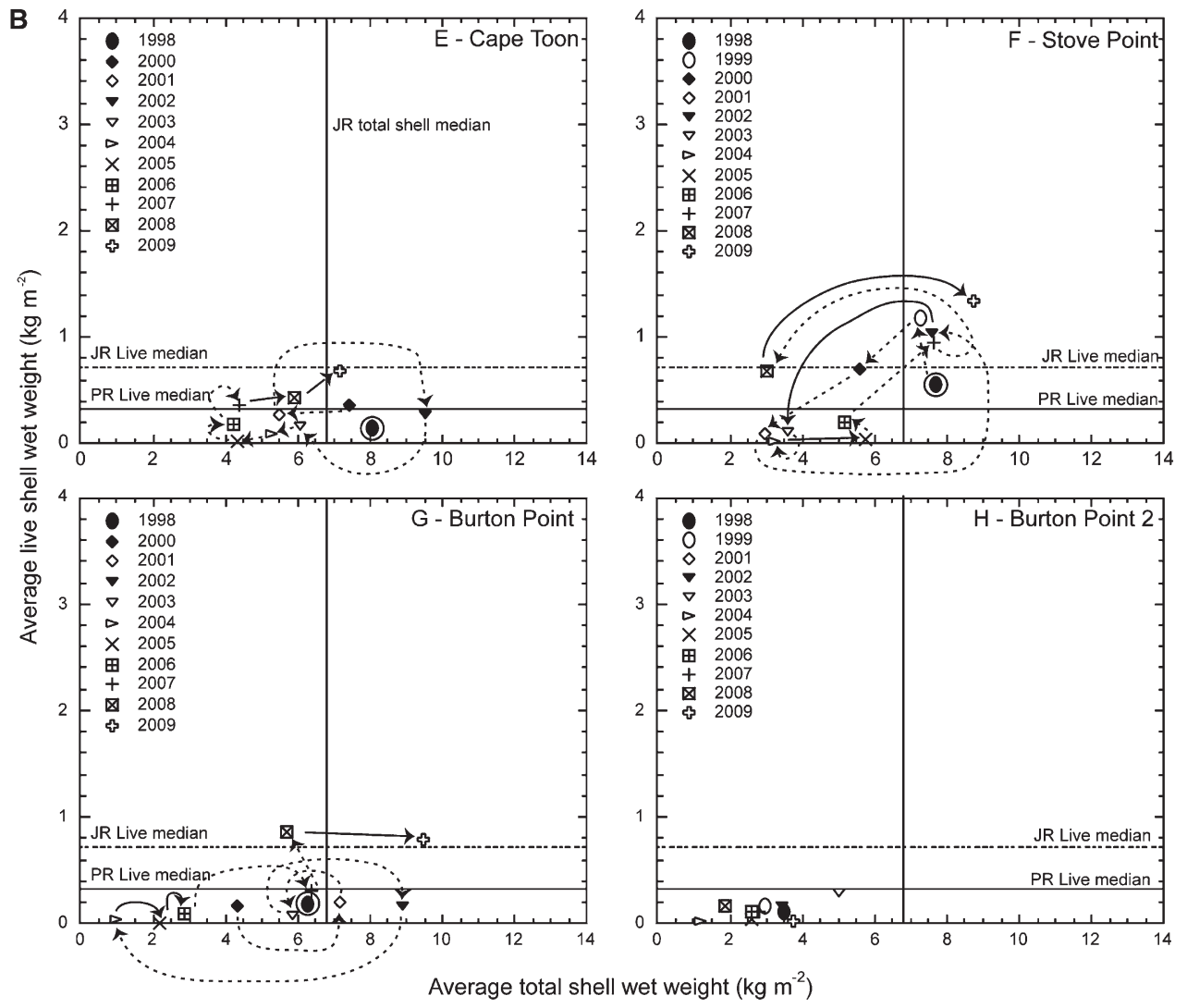

Figure 8. (A-H). Quadrant plots of average live shell wet weight (median, $0.32 \mathrm{~kg} / \mathrm{m}^{2}$ ) versus total shell wet weight (median for James River (JR) public reefs, $=6.77 \mathrm{~kg} / \mathrm{m}^{2}$ (Mann et al. 2009b)) for the 8 Piankatank River (PR) public reefs from 1998 to 2009. Solid arrows indicate transitions between years when shell was added to a particular reef, dotted lines represent transitions between years with no shell additions (see text for more details). 
(Fig. 7B). The quadrants in these plots are defined by the longterm total WSW median from natural self-sustaining reefs in the James River $\left(6.77 \mathrm{~kg} / \mathrm{m}^{2}\right.$ (Mann et al. 2009b)) and the live shell wet weight median from the Piankatank River oyster populations $\left(0.32 \mathrm{~kg} / \mathrm{m}^{2}\right)$. The resulting 4 quadrants are low shell-low live, low shell-high live, high shell-high live, and high shell-low live. An unmanipulated, unharvested self-perpetuating natural oyster reef would be expected to stay in the high shell-high live quadrant over time. Indeed, reefs in the James River
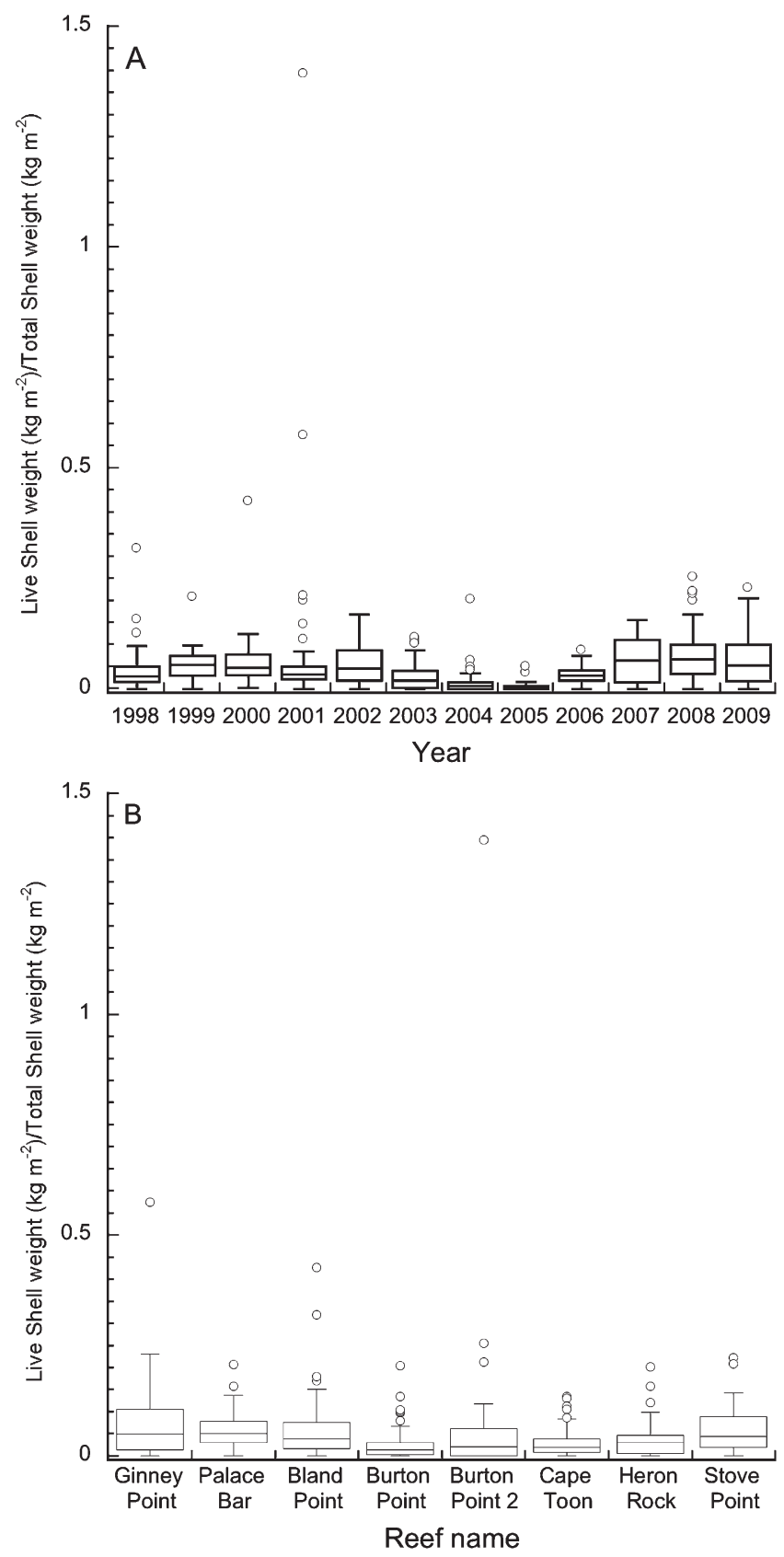

Figure 9. (A, B) The proportion of average live shell wet weight to total shell wet weight by year (A) and reef (B) as measured on the 8 Piankatank River public reefs from 1998 through 2009. Data for each year (A) or reef (B) are represented as the median with $25^{\text {th }}$ and $75^{\text {th }}$ quartiles, as well as minimum and maximum values. characterized as high density $\left(>100\right.$ oysters $\left./ \mathrm{m}^{2}\right)$ by Mann et al. (2009a, Fig. 13) display this stable pattern. Most of the Piankatank public reefs are distributed between the high shellhigh live (31 of 95 data pairs) and the low shell-low live (40/95) condition. These 2 extremes are associated with live oyster populations in good and poor habitat, respectively (Mann et al. 2009b).

If the shell is buried, sinking, or lost, even with a good recruitment, the trajectory may move from high shell-low live to low shell-low live as shell becomes unavailable (Fig. 7A). Subsequent growth of the oysters on a reduced shell base might result in a trajectory from low shell-low live to low shell-high live. Decay of a cohort from a recruitment event (high shellhigh live) should gradually move the points from high shellhigh live to high shell-low live.

A strong recruitment event will move reefs toward the high shell-high live quadrant, as demonstrated by the location of the 1999 and 2002 points (Fig. 7B). After the 1999 recruitment (high shell-high live), the reefs were in the low shell-high live condition in 2000 and 2001. Recruitment in 2002 (high shellhigh live) gave way to low shell-low live conditions in 2003, 2004, 2005, and 2006. This degradation results from the combination of large seed removal in spring 2003, and concurrent density and habitat quality reductions combined with high mortality acting on the remaining oysters. Although shell planting during this period may have increased or at least stabilized habitat quality, in general, recruitment was extremely low in 2003 through 2005. The arrival of the 2006 YOY moved the 2006 point toward high shell-high live, but was not of sufficient magnitude to complete the transition. Subsequent modest recruitments in 2007 and 2008 moved the reefs toward low shell-high live in concert with the growth of these year classes, which contributed to the rehabilitation of the shell base. By 2009, the reefs had moved back to the high shell-high live condition as the product of multiple consecutive years of recruitment and the resulting extension of the live demographic over time combined with mortality to build the available shell base.

Unlike the James River reefs, the public reefs in the Piankatank River were subject to regular shell addition as part of replenishment activity (Table 10). The reef-specific plots (Fig. 8) represent the combination of recruitment, seed removal, and shell planting, with the solid lines corresponding to shell additions. Of the 8 reefs examined, Palace Bar was the only one that was in the high shell-high live condition for at least 10 of the $12 \mathrm{y}$ examined. Burton Point 2, which received no shell addition during the study period, was at the opposite end of the spectrum, occupying the low shell-low live condition for all years. As evidenced by the Ginney Point trajectory, periodic shell addition (solid lines) may not balance losses to shell removal in the face of high disease mortality and sporadic recruitments. Note the descent from 2002 (high shell-high live, with shell addition) through 2005 (low shell-low live). Recruitment in 2006 moved the reef back to high shell-high live, where it remained in 2007 and 2008. The observed shift to low shell-high live in 2009 was probably the result of modest recruitment in 2009, combined with disease-related mortality of the 2006- to 2008-y classes and the gradual decay of the shell base, assuming a half-life of 3-6 y (Powell et al. 2006). The most recent shell repletion activity on Ginney Point was in 2005 (Table 10). 
TABLE 16.

An example of seed harvest options in the Piankatank River under various recruitment and mortality scenarios for a 1-10-y period.

\begin{tabular}{lllll}
\hline \hline Transition & A & B & C & D \\
\hline YOY-Age 1 & 0.50 & 0.70 & 0.75 & 0.85 \\
Age 1-2 & 0.75 & 0.85 & 0.88 & 0.90 \\
Age 2-3 & 0.95 & 0.95 & 0.95 & 0.95 \\
Age 3-4 & 1 & 1 & 1 & 1 \\
\hline
\end{tabular}

Mortality profiles A through D present cumulative proportional mortality for each year class. Seed harvest is given as a proportion of the total river oyster population.

Scenario 1

Mortality profile A. Seed harvest of 0.70 each year after year 1.

\begin{tabular}{lcccccccccc}
\hline \hline \multicolumn{1}{c}{ Age } & $\mathbf{1}$ & $\mathbf{2}$ & $\mathbf{3}$ & $\mathbf{4}$ & $\mathbf{5}$ & $\mathbf{6}$ & $\mathbf{7}$ & $\mathbf{8}$ & $\mathbf{9}$ & $\mathbf{1 0}$ \\
\hline No. of YOY $/ \mathrm{m}^{2}$ & 150 & 480 & 115 & 312 & 142 & 208 & 133 & 148 & 112 & 110 \\
No. $>$ YOY $/ \mathrm{m}^{2}$ & 120 & 96 & 260 & 118 & 173 & 111 & 124 & 93 & 92 \\
Total no. $/ \mathrm{m}^{2}$ & 270 & 576 & 374 & 430 & 315 & 318 & 256 & 242 & 204 \\
Harvest (proportion) & 0 & 0.7 & 0.7 & 0.7 & 0.7 & 0.7 & 0.7 & 0.7 & 0.7 & 186 \\
Total shell accretion & & 11.44 & 17.40 & 30.60 & 27.74 & 21.12 & 21.36 & 17.06 & 16.19 & 13.60 \\
Accretion $>4.55 \mathrm{~L} / \mathrm{m}^{2} / \mathrm{y}$ & & $\mathbf{6 . 8 9}$ & $\mathbf{1 2 . 8 5}$ & $\mathbf{2 6 . 0 5}$ & $\mathbf{2 3 . 1 9}$ & $\mathbf{1 6 . 5 7}$ & $\mathbf{1 6 . 8 1}$ & $\mathbf{1 2 . 5 1}$ & $\mathbf{1 1 . 6 4}$ & $\mathbf{9 . 0 5}$ \\
Accretion $>5.25 \mathrm{~L} / \mathrm{m}^{2} / \mathrm{y}$ & & $\mathbf{6 . 1 9}$ & $\mathbf{1 2 . 1 5}$ & $\mathbf{2 5 . 3 5}$ & $\mathbf{2 2 . 4 9}$ & $\mathbf{1 5 . 8 7}$ & $\mathbf{1 6 . 1 1}$ & $\mathbf{1 1 . 8 1}$ & $\mathbf{1 0 . 9 4}$ & $\mathbf{8 . 3 5}$ \\
Accretion $>6.3 \mathrm{~L} / \mathrm{m}^{2} / \mathrm{y}$ & & $\mathbf{5 . 1 4}$ & $\mathbf{1 1 . 1 0}$ & $\mathbf{2 4 . 3 0}$ & $\mathbf{2 1 . 4 4}$ & $\mathbf{1 4 . 8 2}$ & $\mathbf{1 5 . 0 6}$ & $\mathbf{1 0 . 7 6}$ & $\mathbf{9 . 8 9}$ & $\mathbf{7 . 3 0}$ \\
\hline
\end{tabular}

Scenario 2.

Mortality profile B. Seed harvest of 0.50 each year after year 1 .

\begin{tabular}{lrrrrrrrrrr}
\hline \multicolumn{1}{c}{ Age } & $\mathbf{1}$ & $\mathbf{2}$ & $\mathbf{3}$ & $\mathbf{4}$ & $\mathbf{5}$ & $\mathbf{6}$ & $\mathbf{7}$ & $\mathbf{8}$ & $\mathbf{9}$ & $\mathbf{1 0}$ \\
\hline No. of YOY $/ \mathrm{m}^{2}$ & 150 & 300 & 106 & 194 & 91 & 127 & 73 & 85 & 55 & 58 \\
No. $>$ YOY $/ \mathrm{m}^{2}$ & 75 & 53 & 97 & 46 & 64 & 36 & 43 & 28 & 29 & 21 \\
Total no. $/ \mathrm{m}^{2}$ & 225 & 353 & 203 & 240 & 155 & 164 & 115 & 113 & 85 & 79 \\
Harvest (proportion) & 0 & 0.5 & 0.5 & 0.5 & 0.5 & 0.5 & 0.5 & 0.5 & 0.5 & 0.5 \\
Total shell accretion & & 8.63 & 10.64 & 13.42 & 10.15 & 9.07 & 7.35 & 6.42 & 5.27 & 4.55 \\
Accretion $>4.55 \mathrm{~L} / \mathrm{m}^{2} / \mathrm{y}$ & & $\mathbf{4 . 0 8}$ & $\mathbf{6 . 0 9}$ & $\mathbf{8 . 8 7}$ & $\mathbf{5 . 6 0}$ & $\mathbf{4 . 5 2}$ & $\mathbf{2 . 8 0}$ & $\mathbf{1 . 8 7}$ & $\mathbf{0 . 7 2}$ & 0.00 \\
Accretion $>5.25 \mathrm{~L} / \mathrm{m}^{2} / \mathrm{y}$ & & $\mathbf{3 . 3 8}$ & $\mathbf{5 . 3 9}$ & $\mathbf{8 . 1 7}$ & $\mathbf{4 . 9 0}$ & $\mathbf{3 . 8 2}$ & $\mathbf{2 . 1 0}$ & $\mathbf{1 . 1 7}$ & $\mathbf{0 . 0 2}$ & -0.70 \\
Accretion $>6.3 \mathrm{~L} / \mathrm{m}^{2} / \mathrm{y}$ & & $\mathbf{2 . 3 3}$ & $\mathbf{4 . 3 4}$ & $\mathbf{7 . 1 2}$ & $\mathbf{3 . 8 5}$ & $\mathbf{2 . 7 7}$ & $\mathbf{1 . 0 5}$ & $\mathbf{0 . 1 2}$ & -1.03 & -1.75 \\
\hline
\end{tabular}

Scenario 3.

Mortality profile C. Seed harvest of 0.15 each year after year 1.

\begin{tabular}{|c|c|c|c|c|c|c|c|c|c|c|}
\hline Age & 1 & 2 & 3 & 4 & 5 & 6 & 7 & 8 & 9 & 10 \\
\hline No. of $Y O Y / \mathrm{m}^{2}$ & 150 & 252 & 146 & 230 & 150 & 212 & 152 & 197 & 152 & 184 \\
\hline No. $>$ YOY $/ \mathrm{m}^{2}$ & 63 & 43 & 68 & 44 & 62 & 45 & 58 & 45 & 54 & 44 \\
\hline Total no. $/ \mathrm{m}^{2}$ & 213 & 295 & 214 & 275 & 213 & 257 & 210 & 241 & 206 & 228 \\
\hline Harvest (proportion) & 0 & 0.15 & 0.15 & 0.15 & 0.15 & 0.15 & 0.15 & 0.15 & 0.15 & 0.15 \\
\hline Total shell accretion & & 7.76 & 8.87 & 10.51 & 9.49 & 9.90 & 9.18 & 9.44 & 8.86 & 9.01 \\
\hline Accretion $>4.55 \mathrm{~L} / \mathrm{m}^{2} / \mathrm{y}$ & & 3.21 & 4.32 & 5.96 & 4.94 & 5.35 & 4.63 & 4.89 & 4.31 & 4.46 \\
\hline Accretion $>5.25 \mathrm{~L} / \mathrm{m}^{2} / \mathrm{y}$ & & 2.51 & 3.62 & 5.26 & 4.24 & 4.65 & 3.93 & 4.19 & 3.61 & 3.76 \\
\hline Accretion $>6.3 \mathrm{~L} / \mathrm{m}^{2} / \mathrm{y}$ & & 1.46 & 2.57 & 4.21 & 3.19 & 3.60 & 2.88 & 3.14 & 2.56 & 2.71 \\
\hline
\end{tabular}


TABLE 16. Continued. Scenario 4.

Mortality profile C. Seed harvest of 0.70 every other year after year 1.

\begin{tabular}{|c|c|c|c|c|c|c|c|c|c|c|}
\hline Age & 1 & 2 & 3 & 4 & 5 & 6 & 7 & 8 & 9 & 10 \\
\hline No. of $\mathrm{YOY} / \mathrm{m}^{2}$ & 150 & 252 & 51 & 271 & 25 & 279 & 17 & 283 & 15 & 287 \\
\hline No. $>\mathrm{YOY} / \mathrm{m}^{2}$ & 63 & 43 & 68 & 21 & 70 & 14 & 71 & 13 & 72 & 12 \\
\hline Total no. $/ \mathrm{m}^{2}$ & 213 & 295 & 119 & 292 & 94 & 293 & 88 & 296 & 87 & 299 \\
\hline Harvest (proportion) & 0 & 0.7 & 0 & 0.7 & 0 & 0.7 & 0 & 0.7 & 0 & 0.7 \\
\hline Total shell accretion & & 7.76 & 8.87 & 9.35 & 7.27 & 8.60 & 6.78 & 8.47 & 6.69 & 8.51 \\
\hline Accretion $>4.55 \mathrm{~L} / \mathrm{m}^{2} / \mathrm{y}$ & & 3.21 & 4.32 & 4.80 & 2.72 & 4.05 & 2.23 & 3.92 & 2.14 & 3.96 \\
\hline Accretion $>5.25 \mathrm{~L} / \mathrm{m}^{2} / \mathrm{y}$ & & 2.51 & 3.62 & 4.10 & 2.02 & 3.35 & 1.53 & 3.22 & 1.44 & 3.26 \\
\hline Accretion $>6.3 \mathrm{~L} / \mathrm{m}^{2} / \mathrm{y}$ & & 1.46 & 2.57 & 3.05 & 0.97 & 2.30 & 0.48 & 2.17 & 0.39 & 2.21 \\
\hline
\end{tabular}

Scenario 5 .

Mortality profile D. No seed harvest.

\begin{tabular}{lrrrrrrrrrr}
\hline \multicolumn{1}{c}{ Age } & $\mathbf{1}$ & $\mathbf{2}$ & $\mathbf{3}$ & $\mathbf{4}$ & $\mathbf{5}$ & $\mathbf{6}$ & $\mathbf{7}$ & $\mathbf{8}$ & $\mathbf{9}$ & $\mathbf{1 0}$ \\
\hline No. of YOY $/ \mathrm{m}^{2}$ & 150 & 180 & 102 & 117 & 72 & 77 & 51 & 51 & 35 & 34 \\
No. $>$ YOY $/ \mathrm{m}^{2}$ & 45 & 26 & 29 & 18 & 19 & 13 & 13 & 9 & 8 & 6 \\
Total no. $\mathrm{m}^{2}$ & 195 & 206 & 131 & 136 & 92 & 90 & 64 & 60 & 44 & 40 \\
Harvest (proportion) & 0 & 0 & 0 & 0 & 0 & 0 & 0 & 0 & 0 & 0 \\
Total shell accretion & & $\mathbf{6 . 7 2}$ & $\mathbf{5 . 8 8}$ & $\mathbf{5 . 3 3}$ & $\mathbf{4 . 3 1}$ & $\mathbf{3 . 5 8}$ & $\mathbf{2 . 9 3}$ & $\mathbf{2 . 4 2}$ & $\mathbf{1 . 9 8}$ & $\mathbf{1 . 6 4}$ \\
Accretion $>4.55 \mathrm{~L} / \mathrm{m}^{2} / \mathrm{y}$ & & $\mathbf{2 . 1 7}$ & $\mathbf{1 . 3 3}$ & $\mathbf{0 . 7 8}$ & -0.24 & -0.97 & -1.62 & -2.13 & -2.57 & -2.91 \\
Accretion $>5.25 \mathrm{~L} / \mathrm{m}^{2} / \mathrm{y}$ & & $\mathbf{1 . 4 7}$ & $\mathbf{0 . 6 3}$ & $\mathbf{0 . 0 8}$ & -0.94 & -1.67 & -2.32 & -2.83 & -3.27 & -3.61 \\
Accretion $>6.3 \mathrm{~L} / \mathrm{m}^{2} / \mathrm{y}$ & & $\mathbf{0 . 4 2}$ & -0.42 & -0.97 & -1.99 & -2.72 & -3.37 & -3.88 & -4.32 & -4.66 \\
\hline
\end{tabular}

These 4 mortality profiles (A-D) are applied to population data assuming an initial recruitment (young of the year (YOY) in year 1 of 150 spat $/ \mathrm{m}^{2}$ and a constant recruit-to-stock ratio (R/S) of 4. Both of these values are commensurate with the values observed in the Piankatank River between 1998 and 2009 (Tables 1 and 14). Recruitment and shell accretion are lagged by $1 \mathrm{y}$. Total shell accretion rates $\left(\mathrm{L} / \mathrm{m}^{2} / \mathrm{y}\right)$ are uncorrected for sea level rise, natural degradation, or degradation from seed harvest. An accretion rate of $4.55 \mathrm{~L} / \mathrm{m}^{2} / \mathrm{y}$ is required to maintain equilibrium with sea level rise and natural degradation. An accretion rate of $5.25 \mathrm{~L} / \mathrm{m}^{2} / \mathrm{y}$ is estimated for equilibrium with sea level rise, natural degradation, and degradation from harvest with hand tongs. An accretion rate of $6.3 \mathrm{~L} / \mathrm{m}^{2} / \mathrm{y}$ is estimated for equilibrium with sea level rise, natural degradation, and harvest with dredges. Positive accretion values (in bold type) exceed equilibrium requirements. Negative accretion values (in italics) are less than equilibrium requirements.

At annual timescales, repletion in the form of modest shell planting $\left(\sim 10 \mathrm{~L} / \mathrm{m}^{2}\right.$, Table 10$)$ does shift the total shell-live shell balance toward the high-shell condition. Note the lateral movement from fall 2008 to fall 2009 on Burton Point, with shell planting in early summer 2009 (Fig. 8). Multiple consecutive years of planting at this level or higher result in the observed trajectories and relative stability demonstrated on Ginney Point and Palace Bar. Both these reefs have a history of high disease pressure (Fig. 6) and seed harvest (Table 9); yet, in the long term (12 y), they remain in the high shell-high live (stable) condition 6 out of $12 \mathrm{y}$ and 10 out of $12 \mathrm{y}$, respectively. These plots (Figs. 7 and 8) indicate shell deficits that need to be addressed by repletion on a continuous basis under the current management strategy and natural mortality schedule.

The proportion of live shell weight to total shell weight (measured in kilograms per square meter; Fig. 9) speaks to the long-term shell budget resulting from mortality and shell loss. High-density self-perpetuating reefs in the James River have median ratios of live shell to total shell on the order of 0.33 (Mann et al. 2009b). Median live-to-total shell ratios from the public reefs in the Piankatank range from 0 to $\sim 1.4$, with $8 \%$ higher than 0.2 and $26 \%$ between 0.08 and 0.2 (Fig. 9). These Piankatank values are of the same magnitude as the median ratio values ranging from $0.08-0.18$ observed in poor-quality James River habitats (Mann et al. 2009b, Fig. 12D). Approximately half $(51 \%)$ of the 675 patent tongs considered had live shell-to-total shell ratios between 0.01 and 0.07 . Given this, it is perhaps not surprising that the 1999 and 2002 recruitments do not dramatically increase the median values either in the year of recruitment or the one immediately after (Fig. 9A). Seed removal in 2000 and 2003 is probably responsible for the absence of this signal. The 4 northern reefs have slightly higher live shell-to-total shell medians than the 4 southern reefs (Fig. 9B), in keeping with the higher recorded densities and shell volumes at these locations.

\section{DISCUSSION}

The Piankatank River was described as a river that produced “excellent oysters" as early as the 1930s (Galtsoff et al. 1947). The Piankatank public oyster grounds have been managed as a seed production area since at least 1963, commensurate with "heavy" shell planting activity (Haven et al. 1978). This river has been characterized as a moderate seed area (130-500 spat/ bu) since the early 1970s (Haven et al. 1978). Between 1998 and 2009 , about $30 \%$ of the live oysters in the river were harvested as 
seed oysters, corresponding to about $7.5 \%$ of the total shell base in an average year. Shell planting $(733,382 \mathrm{bu})$ during the 1998 to 2009 period contributed an average of $38 \%$ of the observed shell resource across all reefs. Seed removal (harvest) is effected with dredges, and the process is inherently destructive in areas with a natural shell base. Seed removal during the 1998 to 2009 interval was estimated to be 145,241 bu. In general, for every 5 bushels of shell planted, 1 bushel of seed was harvested $(20 \%$ return). The traditional shell planting coverage target to replenish a preexisting shell base is a minimum of 5,000 bu/acre (Moore 1897, Haven et al. 1978, Kennedy \& Sanford 1999) or $62 \mathrm{~L} / \mathrm{m}^{2}$. Shell planting in the Piankatank during the study period was usually $\sim 10 \mathrm{~L} / \mathrm{m}^{2}$ (Table 10 ), or approximately $17 \%$ of the shell needed to build a firm bottom.

Repletion efforts in support of seed production balance shell planting with lagged seed removal by location. Thus, seed harvest is possible only with continued addition of shell. A lack of natural cultch on the Piankatank River public reefs limited seed production prior to 1963 (Haven et al. 1978) and the onset of a focused VMRC repletion effort. Most oyster repletion or management efforts seek the establishment of self-perpetuating populations over long timescales as the ultimate objective (Powell et al. 2006, Powell \& Klinck 2007, Mann et al. 2009 b). The recent history of this estuary as a focused repletion zone combining shell planting with intensive seed harvest calls into question the relevance of this standard for the Piankatank River in terms of both population demographics and the longterm accumulation or accretion of the shell base.

Although seed removal and shell planting make it difficult to identify a stock-recruit relationship in the Piankatank River on a long-term basis, the recruitment history in the river suggests that regular recruitment is possible even with limited oyster density and a relatively young $(<3-4$ y) demographic. Occasional recruitments in excess of $150 \mathrm{YOY} / \mathrm{m}^{2}$ measured in the fall are observed (Table 12). Indeed, Andrews (1988) credited the hydrodynamics and basin morphology of the Great Wicomico and Piankatank rivers with their ability as seed production rivers. Unlike larger, nontrap-type estuaries, like the James and Rappahannock rivers, it is possible that the Piankatank River may not have had a population demographic with more than 3- or 4-y classes present at any one time since at least the mid 1930s.

Does an unusually high river-specific $\mathrm{R} / \mathrm{S}$ ratio provide opportunity for site-specific management protocols that allow consistent seed harvest quotas, maintain the habitat base, and promote self-perpetuating populations? Table 16 presents an investigation of harvest quotas as a proportion of the total standing stock with regard to selected cumulative mortality profiles (A-D) and recruitment rates over a 10-y time series. For the purposes of investigation, we have set the $\mathrm{R} / \mathrm{S}$ ratio at a conservative value of 4 , noting that this is less than 5.4 observed in the system during years when seed were not removed and densities were more than 10 oysters $/ \mathrm{m}^{2}$.

Four cumulative mortality rates that encompass the observed mortality values from the Piankatank River (1998 to 2009, Table 13) are used, and are noted as A-D in Table 16. Each of 5 scenarios (mortality-accretion combination) was run with an initial YOY density of $150 / \mathrm{m}^{2}$ and an initial age demographic set by the chosen mortality profile. The seed harvest rate was set as a proportion of the total density, and YOY in $\operatorname{year}_{(t+1)}$ is based on an $\mathrm{R} / \mathrm{S}$ ratio for which stock are older than YOY in year ${ }_{t 0}$. The result of the cascading calculation is given in terms of YOY, more than YOY, and total oyster density over a 10-y period. Shell accretion rates are given as a total value for each year, and an annual value in excess of 3 benchmarks. The first benchmark is an accretion rate of $4.55 \mathrm{~L} /$ $\mathrm{m}^{2} / \mathrm{y}$ (Mann et al. 2009a) required for equilibrium based on a sea level increase of $3.5 \mathrm{~mm} / \mathrm{y}$ (Pyke et al. 2008) and a natural shell degradation rate of $30 \%$ (Powell et al. 2006, Powell \& Klinck 2007). The second and third accretion benchmarks are $5.25 \mathrm{~L} / \mathrm{m}^{2} / \mathrm{y}$ and $6.3 \mathrm{~L} / \mathrm{m}^{2} / \mathrm{y}$ based on the same $3.5-\mathrm{mm} / \mathrm{y}$ sea level rise, but with loss rates of $50 \%$ and $80 \%$ respectively. These percentage rates estimate enhanced shell loss rates associated with differing harvest pressures and gears reflecting the expected differences of impact/destruction on the shell base of hand tongs $(50 \%)$ versus dredges $(80 \%)$. Thus, accretion rates with positive values (i.e., supporting a sustainable seed fishery) indicate accretion despite these pressures.

With mortality profile A (Table 16), a 0.7 (70\%) seed harvest from the population within the river is sustainable annually based on shell accretion criteria. With mortality profile $\mathrm{B}$, a 0.5 $(50 \%)$ annual seed harvest is slightly below a sustainable level (scenario 2, Table 16). Mortality profile D (scenario 5, Table 16) is unsustainable even in the absence of seed harvest. Mortality profiles A and D present the extremes observed in the Piankatank River from 1998 through 2009 (Table 13). A successful seed-based repletion program must balance seed removal with natural population processes in an attempt to avoid years of extremely low oyster densities (2004 to 2006, Table 7), which resulted in a moratorium on seed harvest in these years. Mortality profile C can maintain a $0.15(15 \%)$ annual seed harvest (scenario 3, Table 16). However, higher seed yield $(70 \%)$ over the long term may be sustained by imposing harvest moratoriums every other year (scenario 4, Table 16) in the presence of a consistent $\mathrm{R} / \mathrm{S}$ ratio of $\sim 4$.

The fragility of the Piankatank River oyster population is evident from the observed demographic structure in which less than 4-y classes are observed simultaneously. Balanced against this demographic, a consistent $\mathrm{R} / \mathrm{S}$ ratio does suggest that modest sustainable seed harvest is possible within a comprehensive management strategy that incorporates shell planting, annual adjustment of seed quotas, and location-specific seed removal or rotational harvest. This repletion program is clearly dependent on a quantitative fall stock assessment that provides biological and habitat data to support annual adjustment of seed quotas on a site-specific basis using rotational harvest strategies. Evaluation of seed harvest locations with respect to intensity and periodicity over longer timescales predicated on oyster life history are also appropriate.

\section{ACKNOWLEDGMENTS}

This work was supported by funds from the Commonwealth of Virginia to the Virginia Institute of Marine Science and the Virginia Marine Resources Commission. We thank the many individuals who assisted in fieldwork, especially Alan Godshall, Vernon Rowe, John Ericson, Adam Crockett, and Erin Reilly. Todd Nelson designed the hydrographic monitoring station and assisted with station deployment and maintenance. An anonymous reviewer provided helpful comments. This is contribution no. 3119 from the School of Marine Science, Virginia Institute of Marine Science. 


\section{LITERATURE CITED}

Andrews, J. D. 1968. Oyster mortality studies in Virginia. VII. Review of epizootiology and origin of Michinia nelsoni. Proc. Natl. Shellfish. Assoc. 58:23-36.

Andrews, J. D. 1979. Pelecypoda: Ostreidae. In: A. C. Giese \& J. S. Pearse, editors. Reproduction of marine invertebrates. New York: Academic Press. pp. 293-341.

Andrews, J. D. 1988. Epizootiology of the disease caused by the oyster pathogen Perkinsus marinus and its effects on the oyster industry. Amer. Fish. Soc. Spec. Publ. 18:47-63.

Andrews, J. D. 1996. History of Perkinsus marinus, a pathogen of oysters in Chesapeake Bay 1950-1984. J. Shellfish Res. 15:1316.

Andrews, J. D. \& J. L. Wood. 1967. Oyster mortality studies in Virginia. VI. History and distribution of Michinia nelsoni, a pathogen of oysters in Virginia. Chesap. Sci. 8:1-13.

Barbour, P. 1986. The complete works of Captain John Smith (15801631) in three volumes. Volume 2, The generall historie. Chapel Hill: University of North Carolina Press. 485 pp.

Baylor, J. B. 1896. Method of defining and locating natural oyster beds, rocks and shoals. Oyster records (pamphlets, one for each Tidewater, Virginia county, that listed the precise boundaries of the Baylor Survey). Richmond, VA: Board of Fisheries of Virginia. 770 pp.

Bhattacharya, C. G. 1967. A simple method of resolution of a distribution into Gaussian components. Biometrics 23:115-135.

Brooks, W. 1891. The oyster: a popular summary of a scientific study. Baltimore, MD: Johns Hopkins University Press. 230 pp.

Bros, W. E. \& B. C. Cowell. 1987. A technique for optimizing sample size (replication). J. Exp. Mar. Biol. Ecol. 114:63-71.

Burreson, E. M. \& L. M. Ragone Calvo. 1996. Epizootiology of Perkinsus marinus disease of oysters in the Chesapeake Bay with emphasis on data since 1985. J. Shellfish Res. 15:17-34.

Burreson, E. M., M. E. Robinson \& A. Villalba. 1988. A comparison of paraffin histology and hemolymph analysis of the diagnosis of Haplosporidium nelsoni (MSX) in Crassostrea virginica (Gmelin). J. Shellfish Res. 7:19-23.

Carnegie, R. \& E. M. Burreson. 2005. Status of the major oyster diseases in Virginia-2004: a summary of the annual monitoring program. Gloucester Point, VA: Virginia Institute of Marine Science. 14 pp.

Carnegie, R. \& E. M. Burreson. 2006. Status of the major oyster diseases in Virginia-2005: A summary of the annual monitoring program. Gloucester Point, VA: Virginia Institute of Marine Science.14 pp.

Carnegie, R. \& E. M. Burreson. 2009. Status of the major oyster diseases in Virginia 2006-2008: a summary of the annual oyster disease monitoring program. Gloucester Point, VA: Virginia Institute of Marine Science. 20 pp.

Carnegie, R., L. Ragone Calvo \& E. M. Burreson. 2004. Status of the major oyster diseases in Virginia-2003: a summary of the annual monitoring program. Gloucester Point, VA: Virginia Institute of Marine Science. 14 pp.

Chen, H. S., P. V. Hyer, A. Y. Kuo \& C. S. Fang. 1977. Hydrography and hydrodynamics of Virginia estuaries: XI. Mathematical model studies of water quality of the Piankatank estuary. Special report no. 124 in applied marine science and ocean engineering. Gloucester Point, V: Virginia Institute of Marine Science. $80 \mathrm{pp}$.

Chew, K., ed. 1983. Proceedings of the North American Oyster workshop. March 6-8, 1981. Louisiana State University Press. 300 pp.

Ford, S. E. \& H. H. Haskin. 1982. History and epizootiology of Haplosporidium nelsoni (MSX), an oyster pathogen in Delaware Bay, 1957-1980. J. Invertebr. Pathol. 40:118-141.

Galtsoff, P. 1964. The American oyster Crassostrea virginica Gmelin. U.S. Fish Wildlife Service fishery bulletin no. 64. 480 pp.

Galtsoff, P., W. Chipman, Jr., J. B. Engle \& H. N. Calderwood. 1947. Ecological and physiological studies of the effect of sulfate pulp mill wastes on oysters in the York River, Virginia. Fishery bulletin no. 43. U.S. Fish Wildl. Serv. Fish. Bull. 51:59-186.
Harding, J. M., R. Mann \& M. Southworth. 2008. Shell length-at-age relationships in James River oysters (Crassostrea virginica) collected four centuries apart. J. Shellfish Res. 27:1109-1115.

Hargis, W. J., Jr. 1999. The evolution of the Chesapeake oyster reef system during the Holocene Epoch. In: M. W. Luckenbach, R. Mann \& J. A. Wesson, editors. Oyster reef habitat restoration: a synopsis of approaches. Gloucester Point, VA: Virginia Institute of Marine Science. pp. 5-24.

Hargis, W. J., Jr. \& D. S. Haven. 1988. Rehabilitation of the troubled oyster industry of the lower Chesapeake Bay. J. Shellfish Res. 7:271279.

Hargis, W. J., Jr. \& D. S. Haven. 1999. Chesapeake oyster reefs, their importance, destruction and guidelines for restoring them. In: M. W. Luckenbach, R. Mann \& J. A. Wesson, editors. Oyster reef habitat restoration: a synopsis and synthesis of approaches. Gloucester Point, VA: Virginia Institute of Marine Science. pp. 329-358.

Haven, D. S., W. J. Hargis, Jr. \& P. Kendall. 1978. The oyster industry of Virginia: its status, problems, and promise. Special papers in marine science no. 4. Gloucester Point, VA: Virginia Institute of Marine Science. 1024 pp.

Haven, D.S. \& J.P. Whitcomb. 1986. The public oyster bottoms in Virginia: an overview of their size, location, and productivity. Am. Malacol. Bull. 3:17-23.

Haven, D. S., J. P. Whitcomb \& P. Kendall. 1981. The present and potential productivity of the Baylor Grounds in Virginia. Virginia Institute of Marine Science special report in applied marine science and ocean engineering no. 243. Gloucester Point, VA: Virginia Institute of Marine Science. 154 pp.

Kennedy, V. S. \& L. Sanford. 1999. Characteristics of relatively unexploited beds of the eastern oyster, Crassostrea virginica, and early restoration programs. In: M. W. Luckenbach, R. Mann \& J. A. Wesson, editors. Oyster reef habitat restoration: a synopsis and synthesis of approaches. Gloucester Point, VA: Virginia Institute of Marine Science. pp. 25-46.

Mann, R., J. M. Harding \& M. J. Southworth. 2009a. Reconstructing pre-colonial oyster demographics in the Chesapeake Bay, USA. Estuar. Coast. Shelf Sci. 85:217-222.

Mann, R. \& E. N. Powell. 2007. Why oyster restoration goals in the Chesapeake Bay are not and probably cannot be achieved. $J$. Shellfish Res. 26:905-917.

Mann, R., M. J. Southworth, J. M. Harding \& J. Wesson. 2009b. Population studies of the native oyster, Crassostrea virginica (Gmelin), in the James River, Virginia, USA. J. Shellfish Res. 28:193-220.

Moore, H. F. 1897. Oysters and methods of oyster culture. Report of the U.S. Commission of Fish and Fisheries. Washington, DC: US Government Printing Office. pp. 263-340.

Powell, E. N. \& J. M. Klinck. 2007. Is oyster shell a sustainable estuarine resource? J. Shellfish Res. 26:181-194.

Powell, E. N., J. N. Kraeuter \& K. Ashton-Alcox. 2006. How long does oyster shell last on an oyster reef? Estuar. Coast. Shelf Sci. 69: 531-542.

Pyke, C. R., R. G. Najar, M. B. Adams, D. Breitburg, M. Kemp, C. Hershner, R. Howarth, M. Mulholland, M. Paolisso, D. Secor, K. Sellner, D. Wardrop \& R. Wood. 2008. Climate change and the Chesapeake Bay: state of the science review and recommendations. A report from the Chesapeake Bay Program Science and Technical Advisory Committee (STAC). Annapolis, MD: Chesapeake Bay Program. 59 pp.

Ragone Calvo, L. \& E. M. Burreson. 1999. Status of the major oyster diseases in Virginia 1998: a summary of the annual monitoring program. Virginia Institute of Marine Science Marine Resource Report no. 99-3. Gloucester Point, VA: Virginia Institute of Marine Science. $15 \mathrm{pp}$.

Ragone Calvo, L. M. \& E. M. Burreson. 2000. Status of the major oyster diseases in Virginia 1999: a summary of the annual monitoring 
program. Virginia Institute of Marine Science Marine Resource Report no. 00-2. Gloucester Point, VA: Virginia Institute of Marine Science. 23 pp.

Ragone Calvo, L. M. \& E. M. Burreson. 2001. Status of the major oyster diseases in Virginia 2000: a summary of the annual monitoring program. Virginia Institute of Marine Science Marine Resource Report no. 01-8. Gloucester Point, VA: Virginia Institute of Marine Science. $21 \mathrm{pp}$.

Ragone Calvo, L. M. \& E. M. Burreson. 2002. Status of the major oyster diseases in Virginia 2001: a summary of the annual monitoring program. Virginia Institute of Marine Science Marine Resource Report no. 02-1. Gloucester Point, VA: Virginia Institute of Marine Science. 20 pp.

Ragone Calvo, L. M. \& E. M. Burreson. 2003. Status of the major oyster diseases in Virginia 2002: a summary of the annual monitoring program. Virginia Institute of Marine Science Marine Resource Report No. 03-2. Gloucester Point, Virginia. Virginia Institute of Marine Science. 35 p.

Southworth, M., J. M. Harding \& R. Mann. 1999. The status of Virginia's public oyster resource 1998. Virginia marine resources report no. 99-6. Gloucester Point, VA: Virginia Institute of Marine Science. 37 pp.

Southworth, M., J. M. Harding \& R. Mann. 2000. The status of Virginia's public oyster resource 1999. Virginia marine resources report no. 2000-03. Gloucester Point, VA: Virginia Institute of Marine Science. 38 pp.

Southworth, M., J. M. Harding \& R. Mann. 2001. The status of Virginia's public oyster resource 2000: Molluscan Ecology Program. Virginia Institute of Marine Science, Gloucester Point, Virginia. 56 pp.

Southworth, M., J. M. Harding \& R. Mann. 2002. The status of Virginia's public oyster resource 2001. Molluscan Ecology Program. Gloucester Point, VA: Virginia Institute of Marine Science. 53 pp.
Southworth, M., J. M. Harding \& R. Mann. 2003. The status of Virginia's public oyster resource 2002. Molluscan Ecology Program. Gloucester Point, VA: Virginia Institute of Marine Science. 51 pp.

Southworth, M., J. M. Harding \& R. Mann. 2004. The status of Virginia's public oyster resource 2003. Molluscan Ecology Program. Gloucester Point, VA: Virginia Institute of Marine Science. 55 pp.

Southworth, M., J. M. Harding \& R. Mann. 2005. The status of Virginia's public oyster resource 2004. Molluscan Ecology Program. Gloucester Point, VA: Virginia Institute of Marine Science. $51 \mathrm{pp}$.

Southworth, M., J. M. Harding \& R. Mann. 2006. The status of Virginia's public oyster resource 2005. Molluscan Ecology Program. Gloucester Point, VA: Virginia Institute of Marine Science. 49 pp.

Southworth, M., J. M. Harding \& R. Mann. 2007. The status of Virginia's public oyster resource 2006. Molluscan Ecology Program. Gloucester Point, VA: Virginia Institute of Marine Science. 49 pp.

Southworth, M., J. M. Harding \& R. Mann. 2008. The status of Virginia's public oyster resource 2006. Molluscan Ecology Program. Gloucester Point, VA: Virginia Institute of Marine Science. 53 pp.

Southworth, M., J. M. Harding \& R. Mann. 2009. The status of Virginia's public oyster resource 2006. Molluscan Ecology Program. Gloucester Point, VA: Virginia Institute of Marine Science. 51 pp.

Southworth, M., J. M. Harding \& R. Mann. 2010a. The status of Virginia's public oyster resource 2009. Molluscan Ecology Program. Gloucester Point, VA: Virginia Institute of Marine Science. 52 pp.

Southworth, M., J. M. Harding, R. Mann \& J. Wesson. 2010b. Oyster (Crassostrea virginica; Gmelin 1791) population dynamics on public reefs in the Great Wicomico River, Virginia, USA. J. Shellfish Res. 29:271-290

Woods, H., W. J. Hargis, Jr., C. H. Hershner \& P. Mason. 2005. Disappearance of the natural emergent 3-dimensional oyster reef system of the James River, Virginia, 1871-1948. J. Shellfish Res. 24: 139-142. 